\title{
WestVirginiaUniversity
}

THE RESEARCH REPOSITORY @ WVU

Graduate Theses, Dissertations, and Problem Reports

2009

\section{Microbial survival after isoelectric solubilization and precipitation of fish protein}

Lancya Lansdowne

West Virginia University

Follow this and additional works at: https://researchrepository.wvu.edu/etd

\section{Recommended Citation}

Lansdowne, Lancya, "Microbial survival after isoelectric solubilization and precipitation of fish protein" (2009). Graduate Theses, Dissertations, and Problem Reports. 4488.

https://researchrepository.wvu.edu/etd/4488

This Thesis is protected by copyright and/or related rights. It has been brought to you by the The Research Repository @ WVU with permission from the rights-holder(s). You are free to use this Thesis in any way that is permitted by the copyright and related rights legislation that applies to your use. For other uses you must obtain permission from the rights-holder(s) directly, unless additional rights are indicated by a Creative Commons license in the record and/ or on the work itself. This Thesis has been accepted for inclusion in WVU Graduate Theses, Dissertations, and Problem Reports collection by an authorized administrator of The Research Repository @ WVU. For more information, please contact researchrepository@mail.wvu.edu. 


\title{
Microbial Survival After Isoelectric Solubilization and Precipitation of Fish Protein
}

\author{
Lancya Lansdowne
}

Thesis submitted to the

Davis College of Agriculture, Forestry and Consumer Sciences at West Virginia University

in partial fulfillment of the requirements

for the degree of

\author{
Master of Science \\ in \\ Animal and Nutritional Sciences \\ Kristen E. Matak, Ph. D., Chair \\ Jacek Jaczynski, Ph. D. \\ Jianbo Yao, Ph. D.
}

Department of Animal and Nutritional Sciences

Morgantown, West Virginia

2009

Keywords: Listeria innocua, Escherichia coli, isoelectric solubilization/precipitation, trout 


\section{ABSTRACT \\ Microbial Survival After Isoelectric Solubilization and Precipitation of Fish Protein Lancya Lansdowne}

Protein wasted by the disposal of fish processing byproducts may be recovered using isoelectric solubilization and precipitation. The protein is dissolved by extreme $\mathrm{pH}$ shifts and recovered via precipitation and centrifugation. Microbial safety throughout this process had not yet been evaluated; therefore, the purpose of this study was to determine if Listeria innocua and Escherichia coli would survive extreme $\mathrm{pH}$ shifts during the protein recovery process. Fresh rainbow trout were headed, gutted, and minced and then inoculated with $10^{9} \mathrm{CFU} / \mathrm{g}$ E. coli ATCC 25922 or filleted and minced and then inoculated with $10^{9} \mathrm{cfu} / \mathrm{g}$ of $\mathrm{L}$. innocua. The fish was homogenized and brought to the target $\mathrm{pH}$ of 2.0, 3.0, 11.5 or 12.5 by the addition of concentrated hydrochloric acid or sodium hydroxide to solubilize the muscle proteins. The homogenate was blended at $4^{\circ} \mathrm{C}$ for $10 \mathrm{~min}$ and centrifuged to separate the lipid and insoluble components (bones, skin, insoluble protein, etc.) from the protein solution. The lipid and insoluble components were removed and the protein solution was subjected to a second $\mathrm{pH}$ shift (pH 5.5) resulting in protein precipitation. Centrifugation was applied to separate the precipitated proteins from the water. Each constituent (i.e., lipid, insoluble components, protein, and water) was analyzed for bacterial content using non-selective growth media and selective media. The sums of the surviving bacteria in these fractions were compared to the initial inoculum. For $L$. innocua there were no significant differences in recovery on growth or selective media (P > 0.05); implying both acidic and basic conditions have an all-or-nothing bactericidal effect on the gram-positive species. The greatest overall microbial reduction occurred when the $\mathrm{pH}$ was 
shifted to 2.0: a total of 3-log reduction in microbes. Compared to the initial inoculum level in the trout filets, there was a 4-log reduction of Listeria cells in recovered protein. For E. coli, the greatest total microbial reduction occurred when the $\mathrm{pH}$ was shifted to $12.5(P<0.05)$ : a 4.4-log reduction of cells on growth media and a 6.0-log reduction of cells on selective media. Compared to the initial inoculum level in the minced trout, there was a 4.7-log reduction of $E$. coli cells in recovered protein on selective media. There was significant $(P<0.05)$ injury sustained by cells exposed to alkaline treatment ( $\mathrm{pH} 11.5$ and 12.5) in all fractions except the insoluble fraction at $\mathrm{pH}$ 11.5. Increasing the exposure time or the $\mathrm{pH}$, or using a weak organic acid in lieu of a strong acid for Listeria, may result in greater bacterial reductions in the recovered protein. 


\section{ACKNOWLEDGEMENTS}

This work was supported by the USDA Hatch program (project nr WVA00429 and WVA00460) and the USDA Cooperative State Research Education and Extension Service (\#2006-34386-17605).

I would like to thank the faculty and staff of the Department of Animal and Nutritional Sciences for their constant willingness to help and availability, with special thanks extended to Dr. Paul Lewis for my referral to Dr. Kristen Matak and subsequent acceptance into this program. I would like to extend my special gratitude to Sarah Beamer for her unending patience and assistance with this project at all hours of the day and night.

Special thanks go to Dr. Gerald Hobbs of the Department of Community Medicine for generously donating his time to statistical analysis of this project.

I wish to express my deepest thanks to my committee: Dr. Kristen Matak, Dr. Jacek Jaczynski, and Dr. Jianbo Yao, for their valuable instruction, time, and energy spent on assisting me. Thank you all for providing me with this opportunity and helping me to fulfill it. To Dr. Jacek Jaczynski, special thanks for the use of your lab, in which you always made me feel welcome. Dr. Kristen Matak, I offer you my sincerest thanks for your constant support, patience, and guidance. Thank you for your calm and understanding demeanor which helped make this experience enlightening and enjoyable.

Lastly, I would like to thank my family. To my mother, Tonette Lansdowne, thank you for always pushing me forward; to my sisters, Alicia and Jherri Lansdowne, thank you for always supporting me and always making me feel as though all actions were successful ones, no matter the outcome; and to Brian Hutchison, thank you for always being there, none of this would have been possible without you. 


\section{TABLE OF CONTENTS}

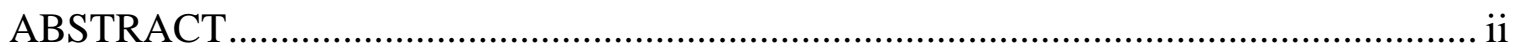

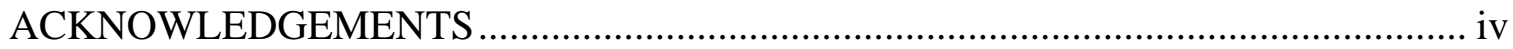

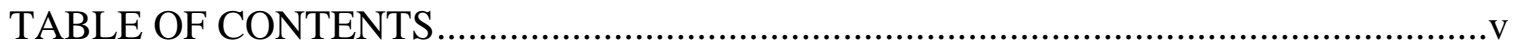

LIST OF FIGURES ……................................................................................ vii

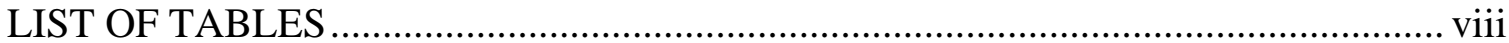

\section{CHAPTER I}

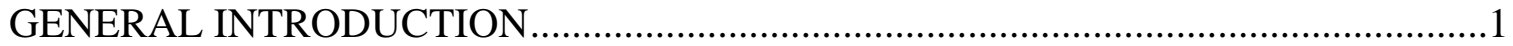

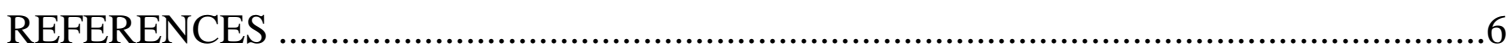

\section{CHAPTER II}

SURVIVAL OF ESCHERICHIA COLI AFTER ISOELECTRIC SOLUBILIZATION AND

PRECIPITATION OF FISH PROTEIN

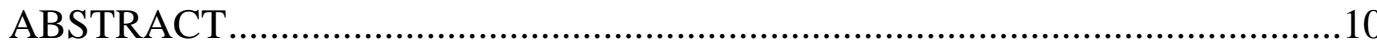

INTRODUCTION ………………………………….................................11

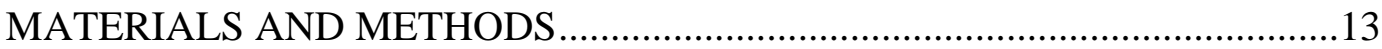

Preparation of fish.....................................................................................

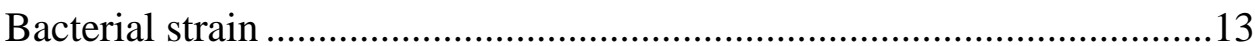

Preparation of inoculum.............................................................................13

Inoculation of fish paste...........................................................................

Isoelectric solubilization/precipitation......................................................14

Microbial analysis .................................................................................14 


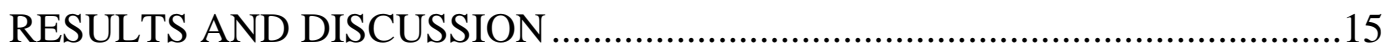

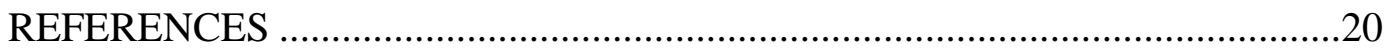

\section{CHAPTER III}

SURVIVAL OF LISTERIA INNOCUA AFTER ISOELECTRIC SOLUBLIZATION AND PRECIPITATION OF FISH PROTEIN

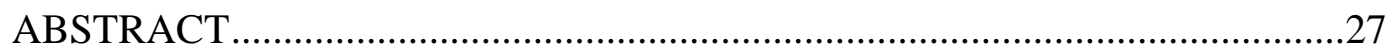

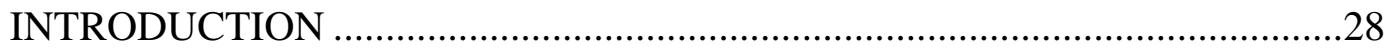

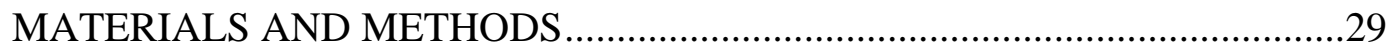

Bacterial strain and inoculum preparation ................................................29

Preparation of fish.....................................................................................

Inoculation of fish paste...........................................................................30

Isoelectric solubilization/precipitation.......................................................

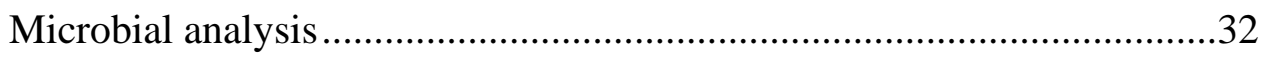

Statistical analyses ………………….....................................................32

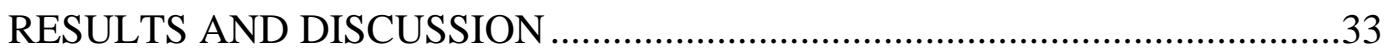

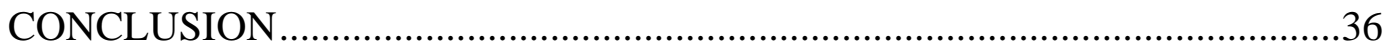

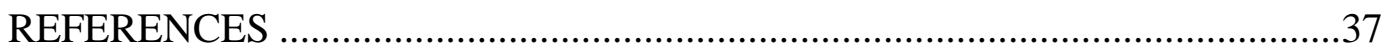




\section{LIST OF FIGURES}

\section{CHAPTER II}

Figure 1. A flowchart for isoelectric solubilization/precipitation for headed and gutted rainbow trout and subsequent analyses of the recovered fractions. 23.

Figure 2. Recovered E. coli at pH 2.0, 3.0, 11.5, and 12.5 on TSA. The left pie charts represent the percentages of inactivated and recovered cells from the initial inoculum level. The pie charts on the right represent what percentages of the recovered cells were found in each fraction. ......24.

Figure 3. Recovered E. coli at $\mathrm{pH}$ 2.0, 3.0, 11.5, and 12.5 on VRBA. The left pie charts represent the percentages of inactivated and recovered cells from the initial inoculum level. The pie charts on the right represent what percentages of the recovered cells were found in each fraction. ......25.

\section{CHAPTER III}

Figure 1. A flowchart for the isoelectric solubilization/precipitation protein recovery process for whole gutted rainbow trout and subsequent analyses of the recovered fractions. .40 .

Figure 2. Recovered L. innocua after acidic pH shift. Pie chart on left represents recovered cells from the initial inoculum; whereas the pie chart on the right represents the amount of cells recovered from each fraction. 41.

Figure 3. Recovered L. innocua after basic $\mathrm{pH}$ shift. Pie chart on left represents recovered cells from the initial inoculum; whereas the pie chart on the right represents the amount of cells recovered from each fraction. 


\section{LIST OF TABLES}

\section{CHAPTER II}

Table 1. Log reduction of E. coli ATCC 25922 exposed to various $\mathrm{pH}$ shifts in different fractions recovered from rainbow trout. Values were determined by subtraction of the log of recovered cells within a fraction from the log of the initial inoculum. Values designated with the same letter within a column and fraction are not significantly different $(\mathrm{P}<0.05)$. Values designated with an asterisk $(*)$ within a row are significantly different $(\mathrm{P}<0.05)$.

\section{CHAPTER III}

Table 1. Log reduction of L. innocua exposed to various $\mathrm{pH}$ shifts in different fractions of rainbow trout. Values were determined by subtraction of the log of recovered cells within a fraction from the log of the total initial inoculation (8.85 log cfu/g). There were no significant differences in recovery on MOX in contrast to TSA+Ye $(\mathrm{P}<0.05)$. 


\section{CHAPTER 1}

\section{GENERAL INTRODUCTION}

In the United States about 33\% of the meat and oil from commercial rainbow trout is lost in the by-products due to inefficient mechanical processing (Torres and others 2007). Since the protein and oil are attached to the bones and within the skin, etc., they are disposed of as byproducts into landfills, animal feed, or compost (Torres and others 2007). The wasted protein, however, can be recovered using a novel process that utilizes isoelectric solubilization and precipitation to retrieve protein and lipids retained by the byproducts of fish processing (heads and frames, etc.). This procedure involves exposing the byproducts to an extremely low or high $\mathrm{pH}$, which separates the insoluble fraction (skin, scales, bones, etc.) and lipids from the protein and water. The protein fraction is then recovered by precipitation at its isoelectric point and centrifugation (Chen and Jaczynski 2007). Further processing may permit the use of recovered protein in value-added human foods (Chen and others 2007, Gigliotti and others 2008).

The antimicrobial effects of strong acids and bases are well-documented. Strong acids, such as $\mathrm{HCl}$, dissociate completely in solutions. This dissociation causes the release of free protons which pass through the cell membrane by interacting with the systems that control the proton flow into and out of the cell, such as electron transport systems (Olson 1993). The free protons, which must be actively removed by the cell, increase in concentration and therefore cause cell death by ATP depletion (Jay and others 2005). In strongly basic solutions, the high pH can solubilize bacterial membrane proteins and lipids (Duncan and others 1972, Labbe and others 1978), which can result in exposure of hydrophobic sites of adjacent lipids to the environment (Jacobsohn and others 1992). One study of exposure of Gram-negative bacteria to alkaline conditions revealed that the bacterial cells tended to clump, indicating that the high $\mathrm{pH}$ 
increased the cells' hydrophobicity (Mendonca and others 1994). Since correct arrangement of membrane lipids is vital to the functionality of the membrane, damage to membrane proteins and lipids by high $\mathrm{pH}$ coupled with exposure of hydrophobic areas of adjacent phospholipids would disrupt the stability of the membrane and predispose it to rupture by intracellular turgor pressure. Bacteria swell and ultimately burst, therefore, due to damage to the protein and lipid components of the cytoplasmic membrane and weakening of the thin peptidoglycan layer of Gram-negative bacteria in basic conditions (Mendonca and others 1994).

Escherichia coli are a facultatively anaerobic Gram-negative fecal coliform bacteria. They are commonly found in ground beef (Samadpour and others 2006) due to fecal contamination from the carcass during processing (Cassin and others 1998), but have also been detected in other foods including apple cider, milk, pork, poultry, lamb, fish, and fresh produce (Meldrum and others 2005, Pao and others 2008, Samadpour and others 1994, Samadpour and others 2006). Diarrhea, hemorrhagic colitis, and hemolytic-uremic syndrome can all be caused by enterohemorrhagic strains of E. coli, including O157:H7 (Doyle and others 1997).

Though cattle are the usual implicated reservoir for E. coli O157:H7, wildlife sharing the same habitat as the cattle may also transmit the pathogenic bacteria. E. coli O157:H7 may be introduced into fresh water systems by cattle via runoff from farms, by the flooding of waste storage ponds in concentrated animal feeding operations due to hurricanes or other adverse weather, or by wild birds. Run-off may in turn contaminate water used in fish farms. Studies have shown that high numbers of $E$. coli O157:H7 were found in the internal organs of catfish (Suhalim and others 2008) and tilapia (Fattal and others 1992) exposed to polluted water containing the pathogen. And while E. coli is not currently listed as a pathogen of concern in 
fish, it may be transmitted to fish via surfaces contaminated by personnel in fish processing plants (Samakupa and others 2003).

E. coli is well-known for its high degree of acid tolerance. It can maintain an internal $\mathrm{pH}$ of 7.4 to 7.8 while growing in an environment with external $\mathrm{pH}$ values ranging from 5 to 9 (Hicke and Hirshfield 1990, Slonczewski and others 1981). Several studies also show the ability of E. coli to survive below the minimum $\mathrm{pH}$ for growth (pH 4.5) (Castanie-Cornet and others 1999, Sinha 1986). Acid tolerance involves maintaining intracellular $\mathrm{pH}$ (Dilworth and Glenn 1999) and is partially understood to involve the ability of cells to repair proton-caused damage to DNA (Rowbury 1995, Sinha 1986). Acid resistance in E. coli may be triggered by the amount of time spent in the intestinal tracts of cattle (Diez-Gonzalez and others 1998). Furthermore, increased fermentation following defecation (Lin and others 1995) acidifies fecal material which could lead to an increased acid tolerance response prior to contamination/run-off. This in turn could lead to infection of fish by acid-resistant $E$. coli on farms. Several studies have shown $E$. coli to be as highly susceptible to alkali pH as other Gram-negative bacteria, with basic conditions causing the cells to enlarge and rupture (Murray and others 1965, Goodson and Rowbury 1989, Mendonca and others 1994).

Listeria monocytogenes is a Gram-positive, aerobic to facultative anaerobic species of bacterium that can be harbored in a variety of foods including meat, dairy products, fresh produce, and raw and cooked fish (Swaminathan, 2001). Listeria monocytogenes poses a threat in the form of listeriosis, an infection which can be fatal in humans with compromised immune systems. Environments supporting Listeria monocytogenes include a variety of food processing plants such as meat, seafood and dairy production; where its presence is particularly difficult to get rid of because of its ability to adhere to surfaces and to form biofilms (Swaminathan, 2001). 
Different processing techniques, including exposure to extreme $\mathrm{pH}$ shifts (Lunden and others 2008), have varying effects on the survival of Listeria within these food-processing plants (Guilbaud and others 2008).

Raw fish ordinarily have low counts of Listeria, though these small amounts may suffice in establishing the initial contaminating populations on surfaces or equipment within fishprocessing plants. Listeria may also be deposited by healthy human carriers of Listeria with poor hygiene, and then be spread throughout the plant by personnel and other equipment (Swaminathan 2001). Listeria populations often linger despite regular use of detergents and sanitizers which may be due to adherence to contact surfaces, including biofilm formation (Swaminathan 2001, Lunden and others 2008). This persistence may lead to contamination of fresh fish which comes into contact with these surfaces and machinery (Swaminathan 2001). Studies on the acid resistance of Listeria show the bacteria to be able to grow below $\mathrm{pH}$ 5.0 (Phan-Thanh and Montagne 1998, Liu and others 2005) and to survive below pH 3.0 (Liu and others 2005, Enache and Chen 2007) for over an hour depending on the composition of the medium (Phan-Thanh and Montagne 1998). In minimal media Listeria die readily at pH 3.0. In rich and complex media, such as tryptic soy broth with yeast, the cells have been shown to survive for an hour (Davis and others 1996, Phan-Thanh and Montagne 1998). Carnitines, betaines, and peptides in rich proteinaceous media modify the fatty acid composition in the membranes of Listeria monocytogenes, resulting in a reduction in proton influx as the $\mathrm{pH}$ of the medium is reduced (Russell and others 1995). This prolongs the internal homeostasis of the bacteria in rich versus minimal media when the $\mathrm{pH}$ is lowered by a strong acid.

In alkaline conditions, studies show Listeria species capable of growing in alkaliadjusted media (Vasseur and others 1999, Cheroutre-Vialette and others 1998) above pH 10.0 
and able to survive over 48 hours at $\mathrm{pH}$ values of 11.0 and 12.0 (Taormina and Beuchat 2001). A study on alkali-stressed L. monocytogenes morphology revealed that the overall integrity of the cells was maintained. This was due to the presence of the peptidoglycan cell wall (Shockman and Barrett 1983) which stabilized the membrane against the turgor pressure exerted by the cytoplasm as it expanded (Csonka 1989) and so prevented the destruction of the cell (Mendonca and others 1994).

At the time of publication of this thesis the effects of the isoelectric solubilization/precipitation process on any microbial populations had not yet been studied. The goal of these studies was therefore to determine the survivability of E. coli and Listeria through the extreme $\mathrm{pH}$ shifts utilized by the procedure. 


\section{REFERENCES}

Cassin MH, Lammerding AM, Todd ECD, Ross W, McColl RS. 1998. Quantitative risk assessment for Escherichia coli O157:H7 in ground beef hamburgers. Int J Food Microbio 41(1):21-44.

Castanie-Cornet M-P, Penfound TA, Smith D, Elliott JF, and Foster JW. 1999. Control of Acid Resistance in Escherichia coli. J Bacteriol 181(11):3525-3535.

Chen YC, Jaczynski J. 2007. Protein recovery from rainbow trout (Oncorhynchus mykiss) processing by-products via isoelectric solubilization / precipitation and its gelation properties as affected by functional additives. J Agric Food Chem 55(22):9079-88.

Chen YC, Tou JC, and Jaczynski J. 2007. Amino acid, fatty acid, and mineral profiles of materials recovered from rainbow trout (Oncorhynchus mykiss) processing by-products using isoelectric solubilization / precipitation. J of Food Science 72(9):C527-535.

Cheroutre-Vialette M, Lebert I, Hebraud M, Labadie JC, Lebert A. 1998. Effects of $\mathrm{pH}$ or $\mathrm{a}_{\mathrm{w}}$ stress on growth of Listeria monocytogenes. Int J Food Microbiol 42(1-2):71-7.

Csonka LN. Physiological and genetic responses of bacteria to osmotic stress. 1989. Microbiol Rev 53(1):121-47.

Davis MJ, Coote PJ; O’Bryne CP. 1996. Acid tolerance in Listeria monocytogenes: The adaptive acid tolerance response (ATR) and growth phase-dependent acid resistance. Microbiology 142(Pt 10):2975-82.

Diez-Gonzalez F, Callaway TR, Kizoulis MG, and Russell JB. 1998. Grain feeding and the dissemination of acid-resistant Escherichia coli from cattle. Science 281(5383):1666-1668.

Dilworth M, Glenn A. 1999. Problems of adverse $\mathrm{pH}$ and bacterial strategies to combat it. Novartis Found Symp 221:4-18.

Doyle MP, Zhao T, Meng J, and Zhao S. 1997. Escherichia coli O157:H7. In: Doyle MP, Beuchat LR, and Montville TJ, editors. Food microbiology: fundamentals and frontiers. Washington, D.C.: American Society for Microbiology Press. p. 171-191.

Duncan CL, Labbe RG, and Reich RR. 1972. Germination of Heat- and Alkali-Altered Spores of Clostridium perfringens Type A by Lysozyme and an Initiation Protein. J Bacteriol 109(2):550559.

Enache E, Chen Y. 2007. Survival of Escherichia coli O157:H7, Salmonella, and Listeria monocytogenes in cranberry juice concentrates at different brix levels. J Food Prot 70(9):2072-7.

Fattal B, Dotan A, and Tchorsh Y. 1992. Rates of experimental microbiological contamination of fish exposed to polluted water. Water Research 26(12):1621-1627. 
Gigliotti J, Jaczynski J, and Tou JC. 2008. Determination of the nutritional value, protein quality and safety of krill protein concentrate isolated using an isoelectric solubilization / precipitation technique. Food Chemistry 111(1):209-214.

Goodson M, Rowbury RJ. 1989. Habituation to alkali in Escherichia coli. Lett Appl Microbiol 9(2):71-73.

Guilbaud M, Chafsey I, Pilet MF, Leroi F, Prevost H, Hebraud M, Dousset X. 2008. Response of Listeria monocytogenes to liquid smoke. J Appl Microbiol 104(6):1744-53.

Hickey EW, Hirshfield IN. 1990. Low-pH-induced effects on patterns of protein synthesis and on internal pH in Escherichia coli and Salmonella typhimurim. Appl Environ Microbiol 56(4):1038-1045.

Jacobsohn MK, Lehman MM, and Jacobsohn GM. 1992. Cell Membranes and Multilamellar Vesicles: Influence of pH on Solvent Induced Damage. Lipids 27(9):694-700.

Jay J, Loessner M, and Golden D. 2005. Food Protection with Chemicals, and by Biocontrol. In: Heldman D, editor. Modern Food Microbiology. $7^{\text {th }}$ ed. Springer, New York, NY. p. 301-350.

Labbe RG, Reich RR, and Duncan CL. 1978. Alteration in ultrastructure and germination of Clostridium perfringens type A spores following extraction of spore coats. Can J Microbiol 24(12):1526-1536.

Lin J, Lee IS, Frey J, Slonczewski JL, and Foster JW. 1995. Comparative analysis of extreme acid survival in Salmonella typhimurium, Shigella flexneri, and Escherichia coli. J Bacteriol 177(14):4097-4104.

Liu D, Lawrence ML, Ainsworth AJ, Austin FW. 2005. Comparative assessment of acid, alkali and salt tolerance in Listeria monocytogenes virulent and avirulent strains. FEMS Microbiol Lett 243(2):373-8.

Lunden J, Tolvanen R, Korkeala H. 2008. Acid and heat tolerance of persistent and nonpersistent Listeria monocytogenes food plant strains. Lett Appl Microbiol 46(2):276-80.

Mendonca AF, Amoroso TL, Knabel SJ. 1994. Destruction of gram-negative food-borne pathogens by high $\mathrm{pH}$ involves disruption of the cytoplasmic membrane. Appl Environ Microbiol 60(11):4009-14.

Meldrum RJ, Ribiero CD, Smith RMM, Walker AM, Simmons M, Worthington D, and Edwards C. 2005. Microbiological Quality of Ready-to-Eat Foods: Results from a Long-Term Surveillance Program (1995 through 2003). J Food Prot 68(8):1654-1658.

Murray RGE, Steed P, and Elson HE. 1965. The location of the mucopeptide in sections of the cell wall of Escherichia coli and other Gram-negative bacteria. Can J Microbiol 11(3):547-560. 
Olson ER. 1993. Influence of pH on bacterial gene expression. Mol Microbiol 8(1):5-14.

Pao S, Ettinger MR, Khalid MF, Reid AO, and Nerrie BL. 2008. Microbial Quality of Raw Aquacultured Fish Fillets Procured from Internet and Local Retail Markets. J Food Prot 71(8):1544-1549.

Phan-Thanh L, Montagne A. 1998. Physiological and biochemical aspects of the acid survival of Listeria monocytogenes. J Gen Appl Microbiol 44(3):183-91.

Rowbury RJ. 1995. An assessment of environmental factors influencing acid tolerance and sensitivity in Escherichia coli, Salmonella spp. and other enterobacteria. Lett Appl Microbiol 20(6):333-337.

Russell NJ, Evans RI, ter Steeg PF, Hellemons J, Verheul A, Abee T. 1995. Membranes as a target for stress adaptation. Int J Food Microbiol 28(2):255-61.

Samadpour M, Ongerth JE, Liston J, Tran N, Nguyen D, Whittam TS, Wilson RA, and Tarr PI. 1994. Occurrence of Shiga-Like toxin-Producing Escherichia coli in Retail Fresh Seafood, Beef, Lamb, Pork, and Poultry from Grocery Stores in Seattle, Washington. Appl Environ Microbiol 60(3):1038-1040.

Samadpour M, Barbour MW, Nguyen T, Cao T-M, Buch F, Depavia GA, Mazengia E, Yang P, Alfi D, Lopes M, and Stopforth JD. 2006. Incidence of Enterohemorrhagic Escherichia coli, Escherichia coli O157, Salmonella, and Listeria monocytogenes in Retail Fresh Ground Beef, Sprouts, and Mushrooms. J Food Prot 69(2):441-443.

Samakupa AP, Einarsson H, and Eyporsdottir A. 2003. Hygiene Indicators in a Fish Processing Establishment - A Case Study in White Fish Processing Establishment. UNU-Fisheries Training Programme 1-29.

Shockman GD, Barrett JF. 1983. Structure, function, and assembly of cell walls of gram-positive bacteria. Annu Rev Microbiol 37:501-27.

Sinha RP. 1986. Toxicity of organic acids for repair-deficient strains of Escherichia coli. Appl Environ Microbiol 51(6):1364-1366.

Slonczewski JL, Rosen BP, Alger JR, and Macnab RM. 1981. pH homeostasis in Escherichia coli: measurement by ${ }^{31} \mathrm{P}$ nuclear magnetic resonance of methylphosphonate and phosphate. Proc Natl Acad Sci USA 78(10):6271-6275.

Suhalim R, Huang Y-W, and Burtle GJ. 2008. Survival of Escherichia coli O157:H7 in channel catfish pond and holding tank water. LWT 41(6):1116-1121. 
Swaminathan B. 2001. Listeria monocytogenes. In: Doyle MP, Beuchat LR, and Montville TJ, editors. Food microbiology: fundamentals and frontiers. 2nd ed. Washington, D.C: ASM Press. p 383-409.

Taormina PJ, Beuchat LR. 2001. Survival and heat resistance of Listeria monocytogenes after exposure to alkali and chlorine. Appl Environ Microbiol 67(6):2555-63.

Torres J, Chen YC, Rodrigo-Garcia J, and Jaczynski J. 2007. Recovery of by-products from seafood-processing streams. In: Shahidi F, editor. Maximising the Value of Marine By-products. Boca Raton, FL: CRC Press Inc. p 65-90.

Vasseur C, Baverel L, Hebraud M, Labadie J. 1999. Effect of osmotic, alkaline, acid or thermal stresses on the growth and inhibition of Listeria monocytogenes. J Appl Microbiol 86(3):469-76. 


\title{
CHAPTER II
}

\section{SURVIVAL OF ESCHERICHIA COLI AFTER ISOELECTRIC SOLUBILIZATION AND PRECIPITATION OF FISH PROTEIN}

\begin{abstract}
Protein recovery for fish processing byproducts utilizes isoelectric solubilization and precipitation. The protein is dissolved by extreme $\mathrm{pH}$ shifts and recovered via precipitation and centrifugation. Microbial survival throughout this process has not yet been evaluated; therefore, the purpose of this study was to determine if $E$. coli would survive exposure to the extreme $\mathrm{pH}$ shifts during the protein recovery process. Fresh rainbow trout were headed, gutted, and minced and then inoculated with approximately $10^{9} \mathrm{CFU} / \mathrm{g}$ E. coli ATCC 25922. The fish was homogenized and brought to the target $\mathrm{pH}$ of $2.0,3.0,11.5$ or 12.5 by the addition of concentrated hydrochloric acid or sodium hydroxide to solubilize muscle proteins. The homogenate was blended at $4^{\circ} \mathrm{C}$ for $10 \mathrm{~min}$ and centrifuged to separate the lipid and insoluble components (bones, skin, insoluble protein, etc.) from the protein solution. The protein solution was subjected to a second $\mathrm{pH}$ shift ( $\mathrm{pH}$ 5.5) resulting in protein precipitation. Centrifugation was applied to separate the precipitated proteins from water. Each fraction (i.e., lipid, insoluble components, protein, and water) was analyzed for bacterial content using growth (tryptic soy agar; TSA) and selective (violet red bile agar; VRBA) media. The sums of the surviving E. coli in these fractions were compared to the initial inoculum. The greatest total microbial reduction occurred when the $\mathrm{pH}$ was shifted to $12.5(P<0.05)$ : a 4.4-log reduction of cells on TSA and a 6.0-log reduction of cells on VRBA. Compared to the initial inoculum level in the minced trout,
\end{abstract}


there was a 4.7-log reduction of cells in recovered protein on VRBA. The use of growth and selective media showed that there was significant $(P<0.05)$ injury sustained to cells exposed to alkaline treatment (pH 11.5 and 12.5) in all fractions except the insoluble fraction at $\mathrm{pH} 11.5$. Increasing the exposure time or the $\mathrm{pH}$ may result in greater bacterial reductions in the recovered protein.

\section{INTRODUCTION}

Escherichia coli are a facultatively anaerobic Gram-negative bacteria which can grow in an environment with external $\mathrm{pH}$ values ranging from 5 to 9 while maintaining internal $\mathrm{pH}$ from 7.4 to $7.8(12,32)$. Enterohemorrhagic strains of E. coli, including O157:H7, can cause diarrhea, hemorrhagic colitis, and hemolytic-uremic syndrome, the latter two conditions being potentially life-threatening (7). While it is a fecal coliform and thus commonly found in ground beef (29), it has been detected in other foods including apple cider, milk, pork, poultry, lamb, fish, and fresh produce $(18,22,28,29)$.

The usual implicated reservoir for E. coli O157:H7 is cattle, though wild animals sharing the same habitat as the cattle may also transmit the pathogenic bacteria. E. coli O157:H7 may be introduced into fresh water systems by cattle via runoff from farms, by the flooding of waste storage ponds in concentrated animal feeding operations due to hurricanes or other adverse weather, or by wild birds. Given that the bacteria can survive in water for long periods of time, run-off may in turn contaminate water used in fish farms. Studies have shown that high numbers of E. coli O157:H7 were found in the internal organs of catfish (33) and tilapia (9) exposed to polluted water containing the pathogen. And while E. coli is not currently listed as a pathogen of 
concern in fish, it may be transmitted to fish in fish processing plants via surfaces contaminated by personnel (30).

About 33\% of the meat and oil from commercial rainbow trout in the United States may be lost in the processing by-products due to inefficient mechanical processing of fish (34). Since the protein and oil are attached to the bones and are within the skin, etc., they are difficult to remove by mechanical processing. Due to this difficulty, they are disposed of as byproducts into landfills, animal feed, or compost (34). However, the wasted protein may be collected and utilized for human consumption using a process where fish byproducts (heads and frames) are exposed to an extremely low or high $\mathrm{pH}$, which separates the insoluble fraction (skin, scales, bones, etc.) and lipids from the protein and water. The protein is then retrieved by precipitation at its isoelectric point and centrifugation $(2,3)$. Further processing may allow the use of recovered proteins in foods fit for human consumption $(4,10)$.

The effect of acid on microbial reduction occurs with the dissociation of the acid within the bacterial cell causing the release of free protons which must be actively removed by the cells. A high concentration of protons thus causes cell death by ATP depletion (14). In strongly basic solutions, damage to the protein and lipid components of the cytoplasmic membrane and weakening of the thin peptidoglycan layer of Gram-negative bacteria contribute to the swelling and ultimate rupture of the cells (19). The antimicrobial effect of the isoelectric solubilization/precipitation process has yet to be determined on Escherichia coli; therefore, the objectives of this study were to determine if $E$. coli would survive the extreme pH shifts associated with the isoelectric solubilization/precipitation process and if so, in which fractions (lipid, protein, water, insoluble components). 


\section{MATERIALS AND METHODS}

Preparation of fish. Preliminary studies showed our fresh rainbow trout (Oncorhynchus mykiss) to have background flora greater than $10^{3} \mathrm{CFU} / \mathrm{g}$; therefore, the fish were headed, gutted, partitioned and dipped for ten seconds into a bath of $50 \mathrm{ppm}$ bleach solution (Clorox Regular-Bleach, Clorox, Oakland, CA, USA). Fresh fish were used instead of post-processing waste to reduce the initial background flora. The sanitized fish segments were minced in a food processor (Prep 11 Plus ${ }^{\mathrm{TM}}$ 11-Cup Food Processor DLC-2011N, Cuisinart, East Windsor, NJ, USA) sanitized with alcohol and UV light. Approximately $300 \mathrm{~g}$ of fish paste was distributed into each freezer bag (Snap N’ Seal Freezer Bags, Kroger Co., Cincinnati, OH, USA), and stored at $-80^{\circ} \mathrm{C}$ until needed for processing. Prior to processing, one bag of fish was set to thaw overnight at $4^{\circ} \mathrm{C}$.

Bacterial strain. Escherichia coli ATCC 25922 was restored in tryptic soy broth (TSB; unless otherwise stated, all media were from Difco, Becton Dickinson, Sparks, MD) and incubated at $35^{\circ} \mathrm{C}$ for $18-24 \mathrm{~h}$. Functioning stocks of this culture were spread onto sterile tryptic soy agar (TSA) slants, incubated for $18-24 \mathrm{~h}$ at $35^{\circ} \mathrm{C}$, and stored at $4^{\circ} \mathrm{C}$.

Preparation of inoculum. Cultures were transferred from the slants to TSB and incubated for 18-24 hours in a rotating incubator (Classic C24, New Brunswick Scientific Co., Inc., Edison, NJ, USA) at $50 \mathrm{rpm}$ and $35^{\circ} \mathrm{C}$. Cells were harvested via centrifugation at $10,000 \times \mathrm{G}$ at $4^{\circ} \mathrm{C}$ for 10 minutes (Sorvall RC-SB refrigerated superspeed centrifuge, Du Pont, Wilmington, DE, USA). The supernatant was removed and the two remaining E. coli pellets were used to inoculate approximately $300 \mathrm{~g}$ fish paste, for a target initial inoculum level of $10^{9} \mathrm{cfu} / \mathrm{g}$. 
Inoculation of fish paste. A bag of thawed fish paste was emptied into a sanitized plastic container (GladWare 8-cup container, The Glad Products Co., Oakland, CA, USA) that had been wiped with alcohol and dried under UV light $(254 \mathrm{~nm})$ for 10 minutes. The E. coli pellets were evenly distributed throughout the mince in the plastic container by stirring with a sterilized spatula for 2 minutes.

Isoelectric solubilization/precipitation. The isoelectric solubilization/precipitation process for protein recovery is shown in Figure $1(2,3)$. After inoculation of the initial $300 \mathrm{~g}$ of fish mince, $214 \mathrm{~g}$ of the mince were blended with $1386 \mathrm{~mL}$ of distilled, deionized water using a homogenizer (PowerGen700, Fisher Scientific, Pittsburgh, PA, USA). 12.1N HCl or 10N NaOH was added to the solution until the desired $\mathrm{pH}(2.0,3.0,11.5$, or 12.5$)$ was attained. The solution was mixed for $10 \mathrm{~min}$ at the target $\mathrm{pH}$ and the fish homogenate was centrifuged at $10,000 \mathrm{x} \mathrm{G}$ for $10 \mathrm{~min}$ at $4^{\circ} \mathrm{C}$ to separate the lipids and insoluble components from the protein solution. The lipid fraction of the homogenate was recovered by pouring the supernatant through a cheese cloth; while the insoluble components remained at the bottom of the centrifuge tube. The remaining supernatant containing the soluble protein and water were brought back to the isoelectric point of the protein (pH 5.5) using $12.1 \mathrm{~N} \mathrm{HCl}$ or $10 \mathrm{~N} \mathrm{NaOH}$. The solution was held at pH 5.5 for 10 minutes. The protein was separated from water using centrifugation at 10,000 x G for 10 minutes at $4^{\circ} \mathrm{C}$. The time for processing ranged between $75-80 \mathrm{~min}$.

Microbial analysis. Microbial analysis was conducted on the uninoculated fish paste, the initial inoculated fish paste, and each of the recovered lipid, insoluble, protein, and water fractions. 
Preliminary studies showed fresh fish to have background flora greater than $10^{3} \mathrm{CFU} / \mathrm{g}$; therefore $1 \mathrm{~g}$ of each fraction was individually mixed with $9 \mathrm{~mL}$ sterile buffered peptone water, producing an initial dilution factor of $10^{-1}$. Fractions requiring further dilutions were serially diluted accordingly with sterile buffered peptone water. Each fraction as spread-plated in duplicate onto growth (TSA) and selective (VRBA) media, and incubated overnight at $35^{\circ} \mathrm{C}$ (Classic C24, New Brunswick Scientific Co., Inc., Edison, NJ, USA). The detection limit for the uninoculated fish paste was $<10^{3} \mathrm{CFU} / \mathrm{g}$, whereas the detection limit for lipid, insoluble, and protein analyses was $<10^{2} \mathrm{CFU} / \mathrm{g}$ and for water $<10^{1} \mathrm{CFU} / \mathrm{g}$.

Statistical analysis. Three experiments were done in triplicate for each $\mathrm{pH}$ value. Microbial counts (cfu/g) were converted into logarithmic units and survival rates of $E$. coli for each fraction were analyzed by Tukey’s Honestly Significant Differences Test $(\mathrm{P}<0.05)($ JMP 7, SAS Institute, Cary, NC, USA). The least squares means plot was used to determine significance between the survival rates on VRBA vs. TSA.

\section{RESULTS AND DISCUSSION}

Background flora was not detected on TSA and VRBA, likely due to the high detection limit $\left(<10^{3} \mathrm{CFU} / \mathrm{g}\right)$ and dipping in the $50 \mathrm{ppm}$ bleach solution. Table 1 shows the total microbial reductions for each $\mathrm{pH}$, for each fraction, and for each media type. The greatest total reduction in cells $(P<0.05)$ in all fractions was seen when the pH was shifted to $12.5(6.00 \log$ and 4.40 log reduction on VRBA and TSA, respectively). There was a statistically significant difference $(P<0.05)$ in recovery on the selective vs. non-selective media, implying that there was significant cell injury. The greatest cell reduction (6.22-log reduction on VRBA and 4.68-log 
reduction on TSA) was seen when the $\mathrm{pH}$ was shifted to 12.5 in the protein fraction $(P<0.05)$; the least reduction in the protein fraction (1.34-logs and 1.43 logs on VRBA and TSA, respectively) was seen at $\mathrm{pH} 3.0(P<0.05)$. The most recovered cells were contained in the insoluble fraction at all $\mathrm{pH}$ values except 12.5 , when most recovered cells were located in the protein fraction. The fewest cells were in the water fraction for all pHs. The relatively high number of recovered cells in the insoluble fraction was likely due to centrifugation. With most surviving cells removed with the insoluble fraction, fewer remained to be removed with the protein during the second centrifugation. At pHs 2.0 and 3.0, protein contained the secondgreatest number of bacterial cells, followed by the lipid fraction. At $\mathrm{pH} 11.5$ the lipid fraction held the second-highest number of recovered cells followed by protein. Lastly, at $\mathrm{pH} 12.5$ the insoluble fraction had the second-highest cell recovery and was followed by lipids (Figures 2 and 3).

In several studies (11,19), E. coli and other Gram-negative bacteria are shown to be highly susceptible to alkali pH due to their thin peptidoglycan layer (20). A study on alkalistressed E. coli and Salmonella enteritidis morphology revealed that Gram-negative bacteria swell and burst in response to basic conditions (19). The rupture of the cells implies that exposure to high $\mathrm{pH}$ is an all-or-nothing event, with cells either surviving with little to no injury or dying as indicated by a lack of growth both on selective media (24) and on non-selective media. This study, however, shows that a large population of $E$. coli was only injured as a result of the extreme alkali shift to $\mathrm{pH} 12.5$, as evidenced by significant differences in recovery on VRBA in contrast to TSA $(P<0.05)$ (Table 1). This injury is also evident at $\mathrm{pH} 11.5$ in the lipid, protein, and water fractions, though the difference in the survival rates of the total recovered cells at $\mathrm{pH} 11.5$ on VRBA as opposed to TSA was not significant. The survival of 
injured E. coli in the basic environment may be related to the composition of the dissolved fish. Rich proteinaceous media provide protection in the forms of carnitines, betaines, and peptides. For example, in Listeria monocytogenes, these components modify the fatty acid composition in the membranes, resulting in a reduction in proton influx as the $\mathrm{pH}$ of the medium is reduced (26). This in turn prolongs the internal homeostasis of the bacteria in rich versus minimal media when the $\mathrm{pH}$ is lowered by a strong acid. While this addresses protection under acidic conditions, it may extend also to basic conditions since it involves the plasma membrane. High $\mathrm{pH}$ can solubilize bacterial membrane proteins and lipids $(8,15)$, which can result in exposure of hydrophobic sites of adjacent lipids to the environment (13). In one study of exposure of Gramnegative bacteria to alkaline conditions (19), the bacterial cells tended to clump, indicating that the high pH increased the cells' hydrophobicity. Since proper arrangement of membrane lipids is vital to the functionality of the membrane, damage to membrane proteins and lipids by high $\mathrm{pH}$ coupled with exposure of hydrophobic areas of adjacent phospholipids would disrupt the stability of the membrane and predispose it to rupture by intracellular turgor pressure. The rich environment provided by fish proteins and other components may contribute to the injury instead of death of cells under basic conditions by prolonging the integrity of the membrane.

E. coli is well-known for its high degree of acid tolerance, which accounts for the low infectious dose of $E$. coli O157:H7. Several studies show the ability of $E$. coli to survive below the minimum $\mathrm{pH}$ for growth ( $\mathrm{pH} 4.5)(1,31)$. Acid tolerance involves maintaining intracellular $\mathrm{pH}$ (6) and is partially understood to involve the ability of cells to repair proton-caused damage to DNA $(25,31)$. E. coli have three identified acid-resistance systems which are activated under specific conditions. There is an acid-induced oxidative system, an arginine-dependent system, and a glutamate-dependent system. In one study, the glutamate-dependent system provided the 
most protection for E. coli at pH 2.0 (17). The glutamate-dependent system was also found to provide protection in the presence of weak acids (17) and required complex media to function (1). The necessity of rich media for the activation of the system which provides the best protection at $\mathrm{pH} 2.0$ reveals how the composition of the fish solution during isoelectric solubilization/precipitation lends to E. coli survival.

Acid resistance in E. coli may be triggered by amount of time spent in intestinal tracts of cattle (5). Furthermore, since increased fermentation following defecation (16) acidifies fecal material; it could lead to an increased acid tolerance response before contamination/run-off. This in turn could lead to infection of fish on farms by acid-resistant E. coli.

Unlike Gram-positive bacteria, the use of weak organic acids instead of strong acids would likely prove ineffective. Strong acids, such as HCl, dissociate completely in solutions. The protons pass through the cell membrane by interacting with the systems that control the proton flow into and out of the cell, such as electron transport systems (21). Weak organic acids, on the other hand, permeate the cell membrane while undissociated and then dissociate once inside the cell, causing the intracellular $\mathrm{pH}$ to lower dramatically and disrupt the cell's metabolic machinery, usually resulting in a more lethal effect (23). However, several studies have revealed that organic acids are relatively ineffective against E. coli, especially O157:H7 (27). This fact combined with the low infectious dose of $E$. coli $\mathrm{O} 157: \mathrm{H7}$ and the general acid resistance of $E$. coli makes isoelectric solubilization/precipitation with alkaline $\mathrm{pH}$ the more reliable alternative for bacterial inactivation.

The isoelectric solubilization/precipitation protein recovery process may be used on other species of fish; however, their final compositions at different solubilization pHs and the effects of their differing compositions on microbes would need to be studied. For example, the mineral 
concentration is higher in rainbow trout proteins recovered at extremely basic or acidic $\mathrm{pH}$ than at relatively intermediate $\mathrm{pH}$. Lipid retention is greater under acidic rather than basic conditions; however, the recovered protein is of higher quality at basic $\mathrm{pH}$ with a greater content of essential amino acids $(3,4,10)$. The presence of minerals and/or lipids may benefit surviving microbial cells, providing them extra nutrients to be used for convalescence.

Though none of the $\mathrm{pH}$ values succeeded in reductions of E. coli ATCC 25922 greater than 5-logs on TSA, pH 12.5 was the most bactericidal pH tested with a 4.40-log reduction of cells. The acidic $\mathrm{pH}$ values were not effective at reducing cells beyond an average of 1.48 logs. The use of selective and non-selective media showed that there was significant injury sustained to cells exposed to alkaline treatment $(\mathrm{pH} 11.5$ and 12.5) in all fractions except the insoluble fraction at $\mathrm{pH}$ 11.5. Microbial reductions may be improved during the isoelectric solubilization/precipitation process by further increasing the $\mathrm{pH}$ or by increasing the exposure time to alkaline conditions. 


\section{REFERENCES}

1. Castanie-Cornet, M.-P., T. A. Penfound, D. Smith, J. F. Elliott, and J. W. Foster. 1999. Control of Acid Resistance in Escherichia coli. J. Bacteriol. 181:3525-3535.

2. Chen, Y., and J. Jaczynski. 2007a. Gelation of protein recovered from whole Antarctic krill (Euphausia superb) by isoelectric solubilization/precipitation as affected by functional additives. J. Agric. Food Chem. 55:1814-1822

3. Chen, Y., and J. Jaczynski. 2007b. Protein recovery from rainbow trout (Oncorhynchus mykiss) processing by-products via isoelectric solubilization / precipitation and its gelation properties as affected by functional additives. Journal of Agricultural and Food Chemistry 55:9079-9088.

4. Chen, Y., J.C. Tou, and J. Jaczynski. 2007. Amino acid, fatty acid, and mineral profiles of materials recovered from rainbow trout (Oncorhynchus mykiss) processing by-products using isoelectric solubilization / precipitation. Journal of Food Science 72:C527-535.

5. Diez-Gonzalez, F., T. R. Callaway, M. G. Kizoulis, and J. B. Russell. 1998. Grain feeding and the dissemination of acid-resistant Escherichia coli from cattle. Science 281:1666-1668.

6. Dilworth, M., and A. Glenn. 1999. Problems of adverse $\mathrm{pH}$ and bacterial strategies to combat it. Novartis Found. Symp. 221:4-18.

7. Doyle, M. P., T. Zhao, J. Meng, and S. Zhao. 1997. Escherichia coli O157:H7, p. 171-191. In M. P. Doyle, L. R. Beuchat, and T. J. Montville (ed.), Food microbiology: fundamentals and frontiers. American Society for Microbiology Press, Washington, D. C.

8. Duncan, C. L., R. G. Labbe, and R. R. Reich. 1972. Germination of Heat- and Alkali-Altered Spores of Clostridium perfringens Type A by Lysozyme and an Initiation Protein. J. Bacteriol. 109:550-559.

9. Fattal, B., A. Dotan, and Y. Tchorsh. 1992. Rates of experimental microbiological contamination of fish exposed to polluted water. Water Research. 26:1621-1627.

10. Gigliotti, J., J. Jaczynski, and J. C. Tou. 2008. Determination of the nutritional value, protein quality and safety of krill protein concentrate isolated using an isoelectric solubilization / precipitation technique. Food Chemistry 111:209-214.

11. Goodson, M., and R. J. Rowbury. 1989. Habituation to alkali in Escherichia coli. Lett. Appl. Microbiol. 9:71-73.

12. Hickey, E. W., and I. N. Hirshfield. 1990. Low-pH-induced effects on patterns of protein synthesis and on internal pH in Escherichia coli and Salmonella typhimurim. Appl. Environ. Microbiol. 56:1038-1045. 
13. Jacobsohn, M. K., M. M. Lehman, and G. M. Jacobsohn. 1992. Cell Membranes and Multilamellar Vesicles: Influence of pH on Solvent Induced Damage. Lipids 27:694-700.

14. Jay, J., M. Loessner, and D. Golden. 2005. Food Protection with Chemicals, and by Biocontrol, p. 301-350. In D. Heldman (ed.), Modern Food Microbiology, $7^{\text {th }}$ edition. Springer, New York, NY.

15. Labbe, R. G., R. R. Reich, and C. L. Duncan. 1978. Alteration in ultrastructure and germination of Clostridium perfringens type A spores following extraction of spore coats. Can. J. Microbiol. 24:1526-1536.

16. Lin, J., I. S. Lee, J. Frey, J. L. Slonczewski, and J. W. Foster. 1995. Comparative analysis of extreme acid survival in Salmonella typhimurium, Shigella flexneri, and Escherichia coli. J. Bacteriol. 177:4097-4104.

17. Lin, J., M. P. Smith, K. C. Chapin, H. S. Baik, G. N. Bennett, and J. W. Foster. 1996. Mechanisms of Acid Resistance in Enterohemorrhagic Escherichia coli. Appl. Environ. Microbiol. 62:3094-3100.

18. Meldrum, R. J., C. D. Ribiero, R. M. M. Smith, A. M. Walker, M. Simmons, D. Worthington, and C. Edwards. 2005. Microbiological Quality of Ready-to-Eat Foods: Results from a Long-Term Surveillance Program (1995 through 2003). J. Food Prot. 68:1654-1658.

19. Mendonca, A., T. Amoroso, and S. Knabel. 1994. Destruction of gram-negative food-borne pathogens by high $\mathrm{pH}$ involves disruption of the cytoplasmic membrane. Appl. Environ. Microbiol. 60:4009-4014.

20. Murray, R. G. E., P. Steed, and H. E. Elson. 1965. The location of the mucopeptide in sections of the cell wall of Escherichia coli and other Gram-negative bacteria. Can. J. Microbiol. 11:547-560.

21. Olson, E. R. 1993. Influence of pH on bacterial gene expression. Mol. Microbiol. 8:5-14.

22. Pao, S., M. R. Ettinger, M. F. Khalid, A. O. Reid, and B. L. Nerrie. 2008. Microbial Quality of Raw Aquacultured Fish Fillets Procured form Internet and Local Retail Markets. J. Food Prot. 71:1544-1549.

23. Phan-Thanh, L., and A. Montagne. 1998. Physiological and biochemical aspects of the acid survival of Listeria monocytogenes. J. Gen. Appl. Microbiol. 44:183-191.

24. Ray, B. 1979. Methods to detect stressed microorganisms. J. Food Prot. 42:346-355.

25. Rowbury, R. J. 1995. An assessment of environmental factors influencing acid tolerance and sensitivity in Escherichia coli, Salmonella spp. and other enterobacteria. Lett. Appl. Microbiol. 20:333-337. 
26. Russell, N. J., R. I. Evans, P. F. ter Steeg, J. Hellemons, A. Verheul, and T. Abee. 1995. Membranes as a target for stress adaptation. Int. J. Food Microbiol. 28:255-261.

27. Ryu, J.-H., Y. Deng, and L. R. Beuchat. 1999. Behavior of Acid-Adapted and Unadapted Escherichia coli O157:H7 When exposed to Reduced pH Achieved with Various Organic Acids. J. Food Prot. 62:451-455.

28. Samadpour, M., J. E. Ongerth, J. Liston, N. Tran, D. Nguyen, T. S. Whittam, R. A. Wilson, and P. I. Tarr. 1994. Occurrence of Shiga-Like toxin-Producing Escherichia coli in Retail Fresh Seafood, Beef, Lamb, Pork, and Poultry from Grocery Stores in Seattle, Washington. Appl. Environ. Microbiol. 60:1038-1040.

29. Samadpour, M., M. W. Barbour, T. Nguyen, T.-M. Cao, F. Buch, G. A. Depavia, E. Mazengia, P. Yang, D. Alfi, M. Lopes, and J. D. Stopforth. 2006. Incidence of Enterohemorrhagic Escherichia coli, Escherichia coli O157, Salmonella, and Listeria monocytogenes in Retail Fresh Ground Beef, Sprouts, and Mushrooms. J. Food Prot. 69:441443.

30. Samakupa, A. P., H. Einarsson, and A. Eyporsdottir. 2003. Hygiene Indicators in a Fish Processing Establishment - A Case Study in White Fish Processing Establishment. UNUFisheries Training Programme. 1-29.

31. Sinha, R. P. 1986. Toxicity of organic acids for repair-deficient strains of Escherichia coli. Appl. Environ. Microbiol. 51:1364-1366.

32. Slonczewski, J. L., B. P. Rosen, J. R. Alger, and R. M. Macnab. 1981. pH homeostasis in Escherichia coli: measurement by ${ }^{31} \mathrm{P}$ nuclear magnetic resonance of methylphosphonate and phosphate. Proc. Natl. Acad. Sci. USA 78:6271-6275.

33. Suhalim, R., Y.-W. Huang, and G. J. Burtle. 2008. Survival of Escherichia coli O157:H7 in channel catfish pond and holding tank water. LWT. 41:1116-1121.

34. Torres, J., Y. Chen, J. Rodrigo-Garcia, and J. Jaczynski. 2007. Recovery of by-products from seafood-processing streams, p. 65-90. In F. Shahidi (ed.), Maximising the Value of Marine Byproducts. CRC Press Inc, Boca Raton, FL. 
Figure 1. A flowchart for isoelectric solubilization/precipitation for headed and gutted rainbow trout and subsequent analyses of the recovered fractions.

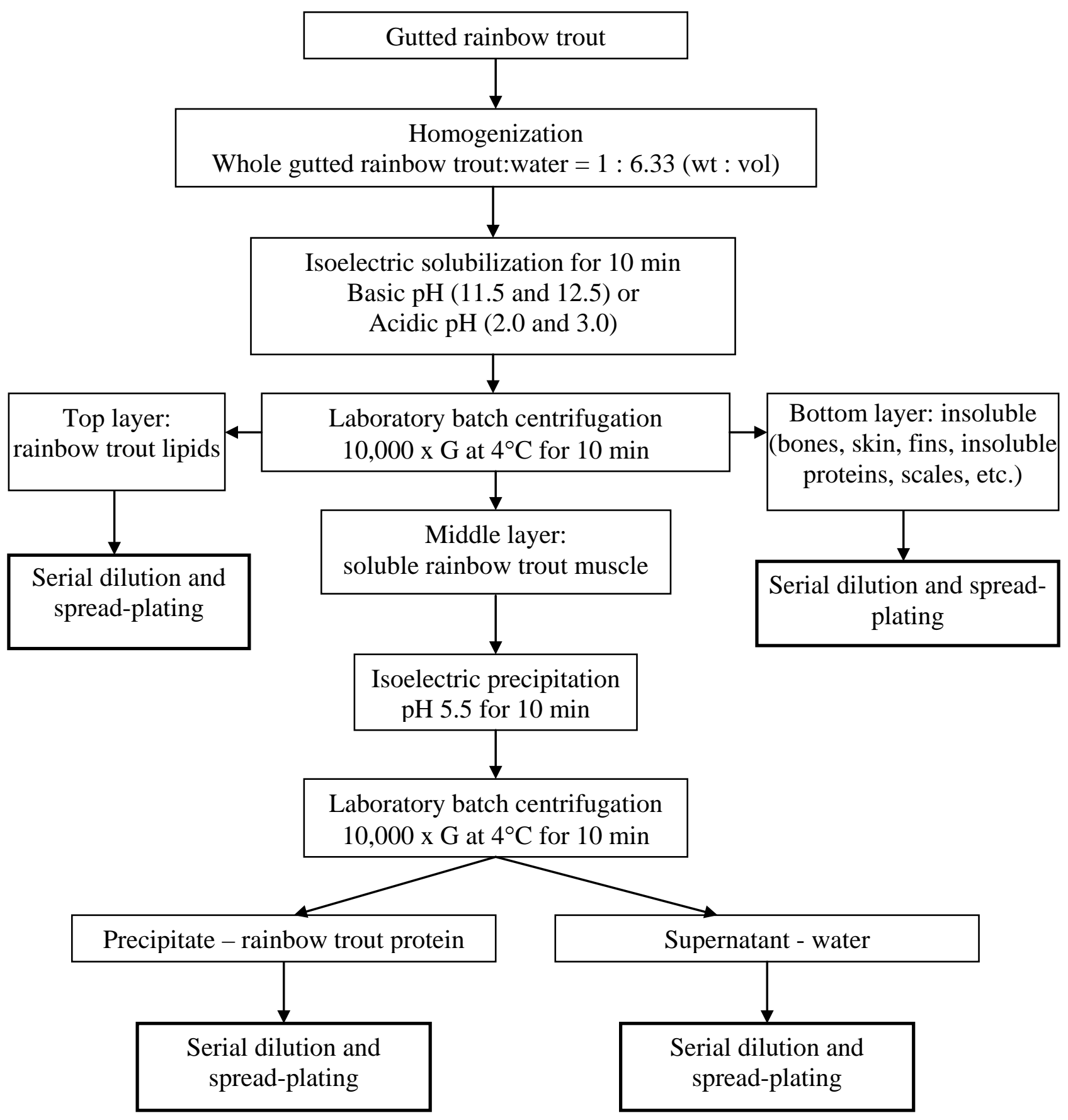


Figure 2. Recovered E. coli at $p H$ 2.0, 3.0,11.5, and 12.5 on TSA. The left pie charts represent the percentages of inactivated and recovered cells from the initial inoculum level. The pie charts on the right represent what percentages of the recovered cells were found in each fraction.

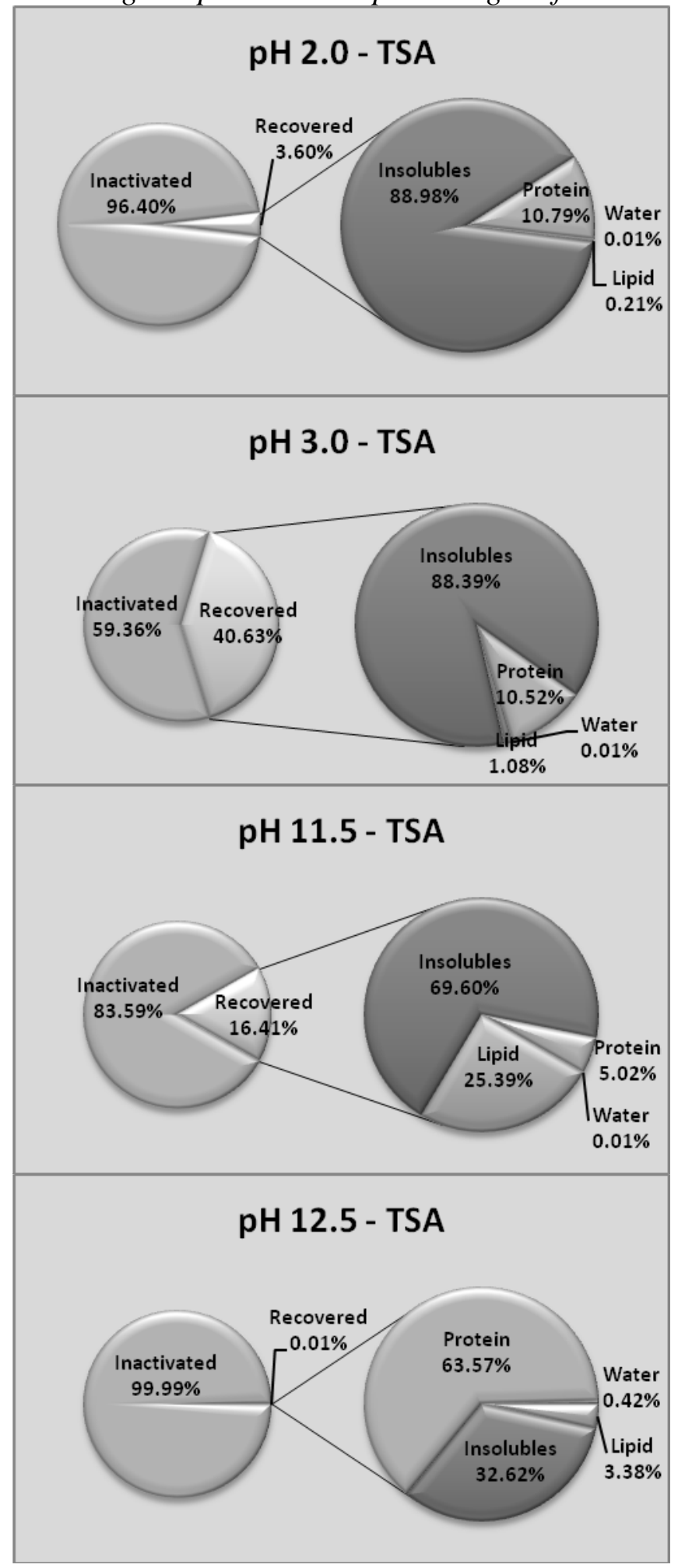


Figure 3. Recovered E. coli at $p H$ 2.0, 3.0,11.5, and 12.5 on VRBA. The left pie charts represent the percentages of inactivated and recovered cells from the initial inoculum level. The pie charts on the right represent what percentages of the recovered cells were found in each fraction.

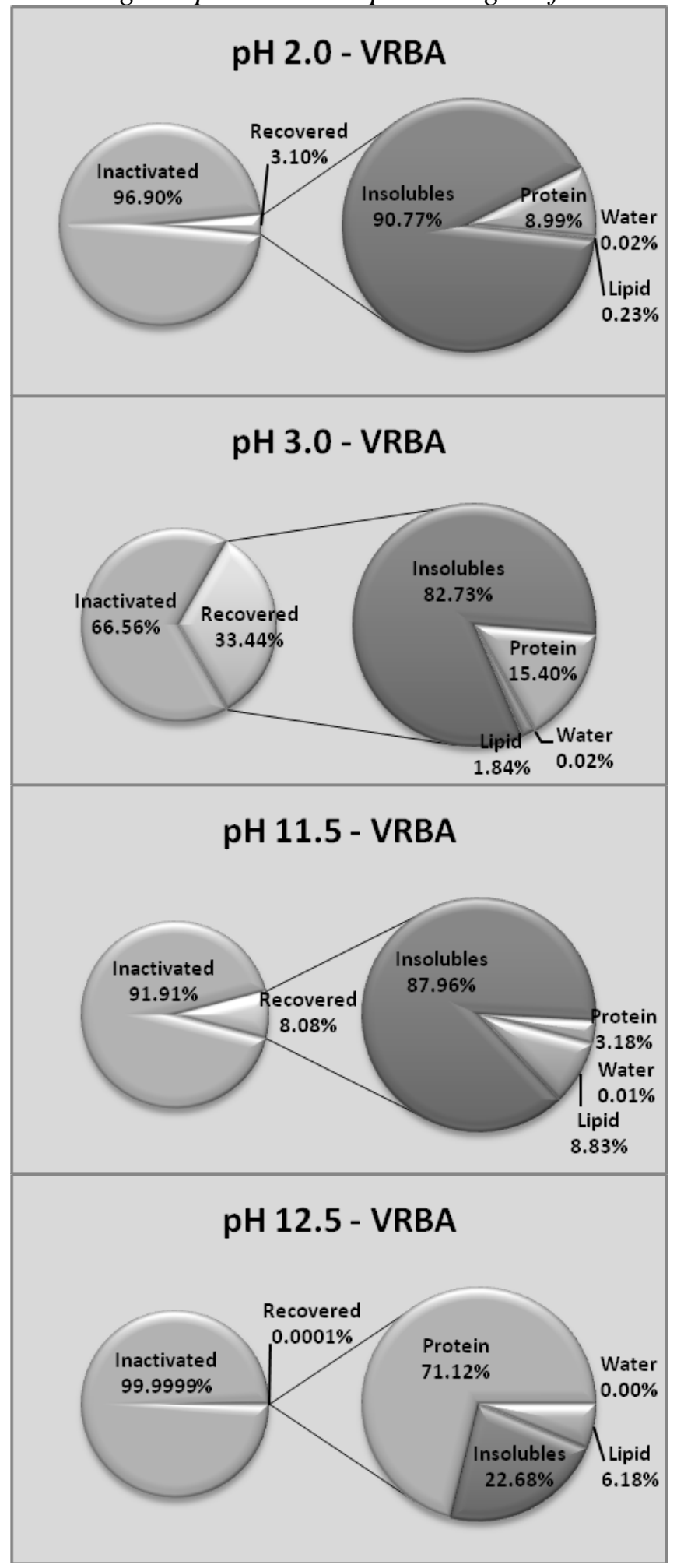


Table 1. Log reduction of E. coli ATCC 25922 exposed to various $p H$ shifts in different fractions recovered from rainbow trout. Values were determined by subtraction of the log of recovered cells within a fraction from the log of the initial inoculum. Values designated with the same letter within a column and fraction are not significantly different $(P<0.05)$. Values designated with an asterisk $\left(^{*}\right)$ within a row are significantly different $(P<0.05)$.

\begin{tabular}{llll}
\hline & & \multicolumn{2}{l}{$\begin{array}{l}\text { Log Reduction (mean log } \\
\text { CFU/g } \pm \text { SD; n=6) }\end{array}$} \\
\cline { 3 - 4 } Fraction & pH & VRBA & TSA \\
\hline Insoluble & 2.0 & $2.06 \pm 1.21^{\mathrm{B}}$ & $1.53 \pm 0.21^{\mathrm{B}}$ \\
& 3.0 & $0.63 \pm 0.19^{\mathrm{B}}$ & $0.56 \pm 0.28^{\mathrm{B}}$ \\
& 11.5 & $1.51 \pm 0.97^{\mathrm{B}}$ & $1.15 \pm 0.58^{\mathrm{B}}$ \\
& 12.5 & $6.61 \pm 0.18^{\mathrm{A}^{*}}$ & $4.89 \pm 0.80^{\mathrm{A}^{*}}$ \\
\hline Lipid & 2.0 & $4.20 \pm 0.26^{\mathrm{B}}$ & $4.27 \pm 0.47^{\mathrm{A}, \mathrm{B}}$ \\
& 3.0 & $2.59 \pm 0.75^{\mathrm{B}}$ & $2.75 \pm 0.81^{\mathrm{B}, \mathrm{C}}$ \\
& 11.5 & $1.96 \pm 1.62^{\mathrm{B}^{*}}$ & $1.44 \pm 1.26^{\mathrm{C}^{*}}$ \\
& 12.5 & $7.20 \pm 0.24^{\mathrm{A}^{*}}$ & $5.78 \pm 0.69^{\mathrm{A}^{*}}$ \\
\hline Protein & 2.0 & $2.61 \pm 0.27^{\mathrm{B}}$ & $2.57 \pm 0.35^{\mathrm{B}}$ \\
& 3.0 & $1.34 \pm 0.18^{\mathrm{C}}$ & $1.43 \pm 0.30^{\mathrm{B}}$ \\
& 11.5 & $2.70 \pm 0.50^{\mathrm{B}^{*}}$ & $2.22 \pm 0.45^{\mathrm{B}^{*}}$ \\
& 12.5 & $6.22 \pm 0.57^{\mathrm{A}^{*}}$ & $4.68 \pm 0.94^{\mathrm{A}^{*}}$ \\
\hline Water & 2.0 & $5.29 \pm 0.11^{\mathrm{B}, \mathrm{C}}$ & $5.29 \pm 0.08^{\mathrm{B}}$ \\
& 3.0 & $4.15 \pm 0.27^{\mathrm{C}}$ & $4.24 \pm 0.47^{\mathrm{B}}$ \\
& 11.5 & $5.40 \pm 0.89^{\mathrm{B}^{*}}$ & $5.04 \pm 0.46^{\mathrm{B}^{*}}$ \\
& 12.5 & $9.15 \pm 0.10^{\mathrm{A}^{*}}$ & $6.76 \pm 0.80^{\mathrm{A}^{*}}$ \\
\hline Total & 2.0 & $1.81 \pm 0.84^{\mathrm{B}}$ & $1.48 \pm 0.21^{\mathrm{B}}$ \\
& 3.0 & $0.54 \pm 0.19^{\mathrm{B}}$ & $0.49 \pm 0.27^{\mathrm{B}}$ \\
& 11.5 & $1.20 \pm 1.18^{\mathrm{B}}$ & $0.81 \pm 0.86^{\mathrm{B}}$ \\
& 12.5 & $6.00 \pm 0.37^{\mathrm{A}^{*}}$ & $4.40 \pm 0.86^{\mathrm{A}^{*}}$ \\
\hline
\end{tabular}




\title{
CHAPTER III
}

\section{SURVIVAL OF LISTERIA INNOCUA AFTER ISOELECTRIC SOLUBLIZATION AND PRECIPITATION OF FISH PROTEIN}

\begin{abstract}
Protein wasted by the disposal of fish processing byproducts may be recovered using isoelectric solubilization and precipitation. Extreme $\mathrm{pH}$ shifts are used to solubilize the protein and then recover it by precipitation and centrifugation. Microbial safety throughout this process has not yet been evaluated; therefore, the purpose of this study was to determine if Listeria innocua would survive extreme $\mathrm{pH}$ shifts during the protein recovery process. Fresh rainbow trout filets were inoculated with approximately $10^{9} \mathrm{cfu} / \mathrm{g}$ of L. innocua, homogenized, and brought to the target $\mathrm{pH}$ of 2.0, 3.0, 11.5 or 12.5 by the addition of concentrated hydrochloric acid or sodium hydroxide. The proteins were allowed to solubilize at $4^{\circ} \mathrm{C}$ for $10 \mathrm{~min}$, centrifuged, and the lipid and insoluble components (bones, skin, insoluble protein, etc.) were removed. A second $\mathrm{pH}$ shift ( $\mathrm{pH}$ 5.5) and centrifugation was used to separate the precipitating protein and water fractions. Each constituent (lipid, protein, water, insoluble components) was analyzed for bacterial content using selective modified oxford agar and non-selective tryptic soy agar supplemented with yeast extract. The sums of the surviving L. innocua in these constituents were compared to the initial inoculum. There were no significant differences in recovery on growth or selective media $(\mathrm{P}>0.05)$; implying both acidic and basic conditions have an all-ornothing bactericidal effect on L. innocua. The greatest microbial reduction occurred when the $\mathrm{pH}$ was shifted to 2.0: a total of 3-log reduction of microbes. Compared to the initial inoculum level
\end{abstract}


in the trout filets, there was a 4-log reduction of cells in recovered protein. Increasing the exposure time, decreasing the $\mathrm{pH}$, or using a weak organic acid in lieu of a strong acid may result in greater bacterial reductions in the recovered protein.

\section{INTRODUCTION}

In the United States generally 33\% of the meat and oil during commercial processing of rainbow trout is lost (Torres and others 2007). Since the protein and oil is attached to the bones and within the skin, etc., they are difficult to remove by mechanical processing and therefore are disposed of as byproducts into landfills, animal feed, or compost (Torres and others 2007). However, the wasted protein can be salvaged and utilized for human consumption using a novel process that uses isoelectric solubilization and precipitation to recover protein and lipid in byproducts of fish processing (heads and frames, etc.). This process involves exposing the byproducts to an extremely low or high $\mathrm{pH}$, which separates the insoluble constituents (skin, scales, bones, etc.) and lipids from the protein and water. The protein fraction is then recovered by precipitation at an optimum isoelectric point and centrifugation (Chen and Jaczynski 2007). Further processing will permit its use in value-added human foods.

Listeria monocytogenes is a Gram-positive, aerobic to facultative anaerobic, halotolerant, psychrotrophic, non-spore-forming, catalase-positive bacterial species responsible for listeriosis. A ubiquitous organism, Listeria monocytogenes can be harbored in a variety of foods including meat, dairy products, fresh produce, and raw and cooked fish (Swaminathan, 2001).

Environments supporting Listeria monocytogenes include a variety of food processing plants such as meat, seafood and dairy production; where its presence is particularly difficult to get rid of because of its ability to adhere to surfaces and to form biofilms (Swaminathan, 2001). Within 
food-processing plants, different processing techniques have varying effects on the survival of Listeria (Guilbaud and others 2008), including exposure to extreme pH shifts (Lunden and others 2008).

The antimicrobial effects of strong acids and bases are well-documented. Acid dissociation within bacterial cells releases free protons which must be actively removed by the cells and consequently cause cell death following ATP depletion (Jay and Loessner 2005). In strongly basic solutions, bacteria swell and ultimately burst (Mendonca and others 1994). Studies on the acid resistance of Listeria show the bacteria to be able to grow below $\mathrm{pH} 5.0$ (Phan-Thanh and Montagne 1998, Liu and others 2005) and to survive below pH 3.0 (Liu and others 2005, Enache and Chen 2007). In alkaline conditions, studies show Listeria species capable of growing above $\mathrm{pH} 10.0$ (and able to survive above $\mathrm{pH} 11.0$ (Taormina and Beuchat 2001).

Thus, as the antimicrobial effect of the isoelectric solubilization/precipitation process has not yet been tested, the objectives of this study were to determine if Listeria innocua would survive the extreme $\mathrm{pH}$ shifts associated with the isoelectric solubilization/precipitation process and if so, in which constituent (lipid, protein, water, insoluble components).

\section{MATERIALS AND METHODS}

Bacterial strain and inoculum preparation. Listeria innocua ATCC 33090 was revived in brain heart infusion (BHI; unless otherwise stated, all media were from Difco, Becton Dickinson, Sparks, MD) and incubated for $18-24 \mathrm{~h}$ at $37^{\circ} \mathrm{C}$. Working stocks of this culture were spread onto sterile slants of tryptic soy agar with $6 \%$ yeast extract (TSA/Ye), incubated at $37^{\circ} \mathrm{C}$ for $18-24 \mathrm{~h}$, and stored at $4^{\circ} \mathrm{C}$. 
Cultures were transferred from the slants to $100 \mathrm{~mL}$ BHI and incubated for 24 hours in a rotary incubator (Classic C24, New Brunswick Scientific Co., Inc., Edison, NJ, USA) at 50 rpm and $37^{\circ} \mathrm{C}$. Cells were harvested by centrifugation at $10,000 \mathrm{x} g$ for 10 minutes at $4^{\circ} \mathrm{C}$ (Sorvall RC-SB refrigerated superspeed centrifuge, Du Pont, Wilmington, DE, USA). The supernatant was poured off and the remaining unwashed pellet was used to inoculate the fish samples. The target initial inoculum level was $10^{9} \mathrm{cfu} / \mathrm{g}$. The actual average initial inoculum level was $7.14 \mathrm{x}$ $10^{8} \mathrm{cfu} / \mathrm{g}$.

Preparation of fish. Rainbow trout (Oncorhynchus mykiss) were headed, gutted, and filleted. Fillets were used instead of frames in order to ensure the recovered protein would be substantial enough for accurate detection of L. innocua. The fillets were dipped for ten seconds into a bath of 50 ppm bleach solution (Clorox Regular-Bleach, Clorox, Oakland, CA, USA) (Clorox Regular-Bleach, Clorox, Oakland, CA, USA). Fresh fish was used as opposed to post-processing fish byproducts in order to reduce the level of background flora. The sanitized fish fillets were ground into a paste in a sanitized food processor (Prep 11 Plus ${ }^{\mathrm{TM}}$ 11-Cup Food Processor DLC2011N, Cuisinart, East Windsor, NJ, USA). The food processor was sanitized by wiping with alcohol and exposing to UV light (254 nm). The fish paste was distributed into freezer bags (Snap N’ Seal Freezer Bags, Kroger Co., Cincinnati, OH, USA), and stored at $-80^{\circ}$ C. Before each trial, one bag of fish was set to thaw overnight at $4^{\circ} \mathrm{C}$.

Inoculation of fish paste. A thawed bag of paste (approximately $300 \mathrm{~g}$ ) was emptied into a sanitized plastic container (GladWare 8-cup container, The Glad Products Co., Oakland, CA, USA). The plastic container was sanitized by wiping with alcohol and exposing to UV light. 
Two L. innocua pellets were mixed into the paste in the plastic container using a sterilized spatula for about 2 minutes. The inoculated fish paste was subjected to the isoelectric solubilization/precipitation process immediately following inoculation.

Isoelectric solubilization/precipitation. A flowchart describing recovery of functional proteins from rainbow trout filets is shown in Figure I. Following inoculation, 214 grams of fish paste were spooned into an autoclaved $2000 \mathrm{~mL}$ glass beaker with an autoclaved spatula. The fish was then blended with $1386 \mathrm{~mL}$ of distilled, deionized water using a homogenizer (PowerGen700, Fisher Scientific, Pittsburgh, PA, USA) sanitized by wiping with alcohol and exposing to UV light. $12.1 \mathrm{~N} \mathrm{HCl}$ or $10 \mathrm{~N} \mathrm{NaOH}$ was added until the solution reached the target $\mathrm{pH}(2.0,3.0$, 11.5, or 12.5). Once at the target $\mathrm{pH}$, the solution was mixed for $10 \mathrm{~min}$ to allow protein solubilization. The homogenized fish slurry was centrifuged at $10,000 \mathrm{x} g$ for $10 \mathrm{~min}$ at $4^{\circ} \mathrm{C}$ (Sorvall RC-SB refrigerated superspeed centrifuge, Du Pont, Wilmington, DE, USA), separating the lipids and insoluble components from the protein solution. The dissolved protein and water were poured from the centrifuge tubes into an autoclaved $2000 \mathrm{~mL}$ beaker through autoclaved cheesecloth. The lipids collected on the cheesecloth and the insoluble components remained at the bottoms of the centrifuge tubes. Both constituents were collected in separate autoclaved 250$\mathrm{mL}$ glass beakers using autoclaved spatulas. The dissolved protein was brought to its isoelectric point (pH 5.5) by the addition of $12.1 \mathrm{HCl}$ or $10 \mathrm{M} \mathrm{NaOH}$ and held for 10 minutes to allow precipitation. The protein and water were separated via centrifugation at $10,000 \times \mathrm{g}$ for 10 minutes at $4^{\circ} \mathrm{C}$. Total processing time was $75-80$ minutes. 
Microbial analysis. Microbial analysis was conducted on the fresh fish paste (i.e., input material in the isoelectric solubilization/precipitation), the initial inoculated fish paste, and all recovered constituents: lipid, recovered insolubles, protein, and water fractions. In separate sterile stomacher bags, $1 \mathrm{~g}$ from each fraction was mixed with $9 \mathrm{~mL}$ of sterilized buffered peptone water. Each constituent was tenfold serially diluted and $0.1 \mathrm{~mL}$ was spread-plated on non-selective (TSA/Ye) and selective (modified oxford agar; MOX) media in duplicate. The plates were incubated at $37^{\circ} \mathrm{C}$ (Classic C24, New Brunswick Scientific Co., Inc., Edison, NJ, USA) for $24 \mathrm{~h}$. The detection limit for the uninoculated fish paste was $<10^{3} \mathrm{CFU} / \mathrm{g}$, for the lipid, insoluble, and protein analyses was $<10^{2} \mathrm{CFU} / \mathrm{g}$, and for water was $<10^{1} \mathrm{CFU} / \mathrm{g}$. The log values of the fractions were calculated by the subtraction of the log of the recovered cells in a fraction from the log of the initial inoculum. The log value of the total recovered cells was calculated by the log of the sum of recovered cells in the four fractions subtracted from the log of the initial inoculum.

Statistical analysis. Three replicated experiments were completed for each $\mathrm{pH}$ value. Microbial counts (cfu/g) were converted into logarithmic units and survival rates of L. innocua for each constituent were analyzed by Tukey’s Honestly Significant Differences Test (P < 0.05) (JMP 7, SAS Institute, Cary, NC, USA). The least squares means plot was used to determine significance between the survival rates on MOX vs. TSA/Ye. The recovered cells were expressed as $\log _{10}$ cfu/g. 


\section{RESULTS AND DISCUSSION}

For all trials, the average background flora of the uninoculated fish paste was approximately $7.5 \times 10^{3} \mathrm{cfu} / \mathrm{g}$ on TSA/Ye. Listeria species was not detected $\left(<10^{3} \mathrm{cfu} / \mathrm{g}\right)$ on MOX. There were no significant differences between the numbers of recovered cells on MOX compared to the number on TSA/Ye $(P<0.05)$; implying both acidic and basic conditions have an all-or-nothing bactericidal effect on $L$. innocua. None of the $\mathrm{pH}$ values tested resulted in a net pasteurization effect (a 6-log reduction in microbial population) (USDA 2001). In the protein fraction, the greatest cell reduction (3.70-log cfu/g reduction) occurred when the $\mathrm{pH}$ was shifted to 2.0; the least reduction (1.08-log cfu/g) occurred at pH 11.5 (Table I). Most recovered cells were contained in the insoluble portion and the fewest in water. The relatively high number of recovered cells in the insoluble constituent was likely due to centrifugation. With most survivors removed with the insolubles fraction, fewer remained to be collected with the protein during the second centrifugation. At all $\mathrm{pH}$ values except 11.5, the protein fraction contained the secondlargest number of recovered cells, followed by the lipid fraction (Figures II and III). Lipids contained more recovered cells at $\mathrm{pH} 11.5$ than protein.

L. innocua survives approximately 1 hour in a strongly acidic environment; Listeria monocytogenes also survives an hour of exposure to $\mathrm{pH} 3.0$ depending on the composition of the medium (Phan-Thanh and Montagne 1998). In minimal media composed of Premaratne’s modification of Wilshimer's broth with additional vitamins (Phan-Thanh and Gormon 1997), Listeria die readily at $\mathrm{pH}$ 3.0. In rich and complex media, such as tryptic soy broth with yeast, the cells have been shown to survive for an hour (Davis and others 1996, Phan-Thanh and Montagne 1998). Rich proteinaceous media provide protection in the forms of carnitines, betaines, and peptides. These components modify the fatty acid composition in the membranes 
of Listeria monocytogenes, resulting in a reduction in proton influx as the $\mathrm{pH}$ of the medium is reduced (Russell and others 1995). This in turn prolongs the internal homeostasis of the bacteria in rich versus minimal media when the $\mathrm{pH}$ is lowered by a strong acid. Fish proteins and other components may contribute to the decreased antimicrobial effectiveness of the acid by providing a similarly rich environment. Furthermore, Listeria cells in the stationary phase, which would likely be the phase of the contaminating cells in fish-processing plants, naturally acquire some degree of acid tolerance (Davis and others 1996, O’Driscoll and others 1996). To combat this, a weak organic acid such as acetic acid, which has a greater bactericidal effect than $\mathrm{HCl}$ at equal pH values (Phan-Thanh and Montagne 1998), may be used to lower pH instead of a strong acid. Strong acids, such as $\mathrm{HCl}$, dissociate completely in solutions. The protons pass through the cell membrane by interacting with the systems that control the proton flow into and out of the cell, such as electron transport systems (Olson 1993). Weak organic acids, on the other hand, permeate the cell membrane while undissociated and then dissociate once inside the cell, causing the intracellular $\mathrm{pH}$ to lower dramatically and disrupt the cell's metabolic machinery, resulting in a more lethal effect (Phan-Thanh and Montagne 1998). Quality differences in protein harvested using organic as opposed to inorganic acids would need to be tested.

$L$. innocua was more resistant to basic conditions than acidic ones. Similarly, $L$. monocytogenes will not only survive over 48 hours at $\mathrm{pH}$ values of 9.0, 10.0, 11.0, and 12.0 (Taormina and Beuchat 2001) but will grow in alkali-adjusted media (Vasseur and others 1999, Cheroutre-Vialette and others 1998). A study on alkali-stressed L. monocytogenes morphology revealed that while Gram-negative bacteria leak and collapse in response to basic conditions, Gram-positive L. monocytogenes cells maintained their overall integrity. This is due to the presence of the peptidoglycan cell wall (Shockman and Barrett 1983). As the cytoplasm expands 
and presses the cell membrane against the surrounding wall, it stabilizes the membrane against the turgor pressure exerted by the cytoplasm (Csonka 1989) and so prevents the swelling and ultimate bursting of the cell (Mendonca and others 1994). Furthermore, in response to a strongly basic environment, bacterial cells can use cytoplasmic buffering via synthesis of intracellular metabolites to attempt to stabilize $\mathrm{pH}$ (Dilworth and Glenn 1999). While this is only a temporary fix to oppose the increasing $\mathrm{OH}^{-}$concentration, relatively short exposure time during isoelectric solubilization/precipitation makes it a viable rationalization for the better survival of L. innocua at $\mathrm{pH} 11.5$ and 12.5 in contrast to 2.0 and 3.0.

The rupture of the cells implies that exposure to high $\mathrm{pH}$ is an all-or-nothing event, with cells either surviving with little to no injury or dying. This is indicated by a lack of growth on both selective and non-selective media since only healthy, uninjured cells can be recovered on selective media (Ray 1979). These findings are consistent with those found in another study (Mendonca and others 1994) in that there were no significant differences between the numbers of recovered cells on the selective and non-selective media $(P<0.05)$ (Table I).

Generally, raw fish have low counts of Listeria; contamination often occurs from contact with the fish-processing environment where Listeria populations often linger despite regular use of detergents and sanitizers (Swaminathan 2001). Initial contamination of surfaces and equipment is from sources such as the incoming raw fish or healthy human carriers of Listeria with poor hygiene (Swaminathan 2001). The contamination is then spread throughout the plant by personnel and other equipment. Persistence of Listeria in these conditions may be due to adherence to contact surfaces, including biofilm formation (Swaminathan 2001; Lunden and others 2008). The Listeria which contaminate fish byproducts in plants may therefore be more likely to be lingering persistent strains. One study (Lunden and others 2008) found that 
persistence is related to acid tolerance, with cells that are more acid resistant lingering longer than the acid-sensitive. If the contaminating strains in fish plants are indeed persistent strains, they may have a greater degree of acid tolerance than expected and may be more resistant to the pH shifts.

The isoelectric solubilization/precipitation protein recovery process may be used on other species of fish; however, their final compositions at different solubilization pHs and the effects of their differing compositions on microbes would need to be studied. For example, the mineral concentration is higher in rainbow trout proteins recovered at extremely basic or acidic $\mathrm{pH}$ than at relatively intermediate $\mathrm{pH}$. Lipid retention is also higher under acidic rather than basic conditions (Chen and Jaczynski 2007). At basic pH, however, the recovered protein is of higher quality with a greater content of essential amino acids than that recovered at acidic $\mathrm{pH}$ (Chen and others 2007). The presence of minerals and/or lipids and the quality of recovered protein may benefit any surviving microbial cells, providing them extra nutrients to be used for convalescence.

\section{CONCLUSION}

This study examined the effect of a protein recovery process that employs extensive $\mathrm{pH}$ shifts on the reduction of Listeria innocua in fish. Neither extreme $\mathrm{pH}$ value of 2.0 or 12.5 resulted in a net pasteurization effect (a 6-log reduction in microbial population), though $\mathrm{pH} 2.0$ resulted in the smallest surviving population in protein and overall. There was no significant difference in recovery on growth or selective media $(P<0.05)$, indicating minimal sublethal injury of cells. Future studies will continue to look at the effects of using a organic, rather than inorganic, acid for protein solubilization. 


\section{REFERENCES}

Chen YC, Jaczynski J. 2007. Protein recovery from rainbow trout (Oncorhynchus mykiss) processing by-products via isoelectric solubilization / precipitation and its gelation properties as affected by functional additives. J Agric Food Chem 55(22):9079-88.

Chen YC, Tou JC, Jaczynski J. 2007. Amino acid, fatty acid, and mineral profiles of materials recovered from rainbow trout (Oncorhynchus mykiss) processing by-products using isoelectric solubilization / precipitation. J Food Sci 72(9):C527-35.

Cheroutre-Vialette M, Lebert I, Hebraud M, Labadie JC, Lebert A. 1998. Effects of $\mathrm{pH}$ or $\mathrm{a}_{\mathrm{w}}$ stress on growth of Listeria monocytogenes. Int J Food Microbiol 42(1-2):71-7.

Csonka LN. Physiological and genetic responses of bacteria to osmotic stress. 1989. Microbiol Rev 53(1):121-47.

Davis MJ, Coote PJ; O’Bryne CP. 1996. Acid tolerance in Listeria monocytogenes: The adaptive acid tolerance response (ATR) and growth phase-dependent acid resistance. Microbiology 142(Pt 10):2975-82.

Dilworth MJ, Glenn AR. 1999. Problems of adverse pH and bacterial strategies to combat it. Novartis Found Symp 221:4-18.

Enache E, Chen Y. 2007. Survival of Escherichia coli O157:H7, Salmonella, and Listeria monocytogenes in cranberry juice concentrates at different brix levels. J Food Prot 70(9):2072-7.

Guilbaud M, Chafsey I, Pilet MF, Leroi F, Prevost H, Hebraud M, Dousset X. 2008. Response of Listeria monocytogenes to liquid smoke. J Appl Microbiol 104(6):1744-53.

Jay J, Loessner M, Golden D. 2005. Food Protection with Chemicals, and by Biocontrol. In: Heldman D, editor. Modern Food Microbiology. $7^{\text {th }}$ ed. New York: Springer. p 301-50.

Liu D, Lawrence ML, Ainsworth AJ, Austin FW. 2005. Comparative assessment of acid, alkali and salt tolerance in Listeria monocytogenes virulent and avirulent strains. FEMS Microbiol Lett 243(2):373-8.

Lunden J, Tolvanen R, Korkeala H. 2008. Acid and heat tolerance of persistent and nonpersistent Listeria monocytogenes food plant strains. Lett Appl Microbiol 46(2):276-80.

Mendonca AF, Amoroso TL, Knabel SJ. 1994. Destruction of gram-negative food-borne pathogens by high $\mathrm{pH}$ involves disruption of the cytoplasmic membrane. Appl Environ Microbiol 60(11):4009-14.

O’Driscoll B, Gahan CG, Hill C. 1996. Adaptive acid tolerance response in Listeria monocytogenes: isolation of an acid-tolerant mutant which demonstrates increased virulence. Appl Environ Microbiol 62(5):1693-98. 
Olson ER. 1993. Influence of pH on bacterial gene expression. Mol Microbiol 8(1):5-14.

Phan-Thanh L, Gormon T. 1997. A chemically defined minimal medium for the optimal culture of Listeria. Int J Food Microbiol 35(1):91-5.

Phan-Thanh L, Montagne A. 1998. Physiological and biochemical aspects of the acid survival of Listeria monocytogenes. J Gen Appl Microbiol 44(3):183-91.

Ray B. 1979. Methods to detect stressed microorganisms. J Food Prot 42:346-55.

Russell NJ, Evans RI, ter Steeg PF, Hellemons J, Verheul A, Abee T. 1995. Membranes as a target for stress adaptation. Int J Food Microbiol 28(2):255-61.

Shockman GD, Barrett JF. 1983. Structure, function, and assembly of cell walls of gram-positive bacteria. Annu Rev Microbiol 37:501-27.

Swaminathan B. 2001. Listeria monocytogenes. In: Doyle MP, Beuchat LR, and Montville TJ, editors. Food microbiology: fundamentals and frontiers. 2nd ed. Washington, D.C: ASM Press. p 383-409.

Taormina PJ, Beuchat LR. 2001. Survival and heat resistance of Listeria monocytogenes after exposure to alkali and chlorine. Appl Environ Microbiol 67(6):2555-63.

Torres JA, Chen Y, Rodrigo-Garcia J, Jaczynski J. 2007. Recovery of by-products from seafoodprocessing streams. In: Shahidi F, editor. Maximising the Value of Marine By-products. Boca Raton, FL: CRC Press Inc. p 65-90.

US Food and Drug Administration. 2001. Fish and Fisheries Products Hazards and Controls Guidance: Chapter 17. http://www.cfsan.fda.gov/ comm/haccp4q.html. Accessed on: September 16, 2008.

Vasseur C, Baverel L, Hebraud M, Labadie J. 1999. Effect of osmotic, alkaline, acid or thermal stresses on the growth and inhibition of Listeria monocytogenes. J Appl Microbiol 86(3):469-76. 
Table 1. Log reduction of L. innocua exposed to various $p H$ shifts in different fractions of rainbow trout. Values were determined by subtraction of the log of recovered cells within a fraction from the log of the total initial inoculation $(8.85 \log$ cfu/g). There were no significant differences in recovery on MOX in contrast to TSA+Ye $(P<0.05)$.

\begin{tabular}{|c|c|c|c|}
\hline \multirow[b]{2}{*}{ Fraction } & \multirow[b]{2}{*}{$\mathrm{pH}$} & \multicolumn{2}{|c|}{$\begin{array}{l}\text { Log Reduction (mean log } \\
\text { cfu/g } \pm S D ; n=6 \text { ) }\end{array}$} \\
\hline & & MOX & TSA/Ye \\
\hline \multirow[t]{4}{*}{ Insoluble } & 2.0 & $3.20 \pm 0.56^{\mathrm{A}}$ & $3.20 \pm 0.41^{\mathrm{A}}$ \\
\hline & 3.0 & $0.99 \pm 0.34^{\mathrm{B}}$ & $1.05 \pm 0.25^{\mathrm{B}}$ \\
\hline & 11.5 & $0.32 \pm 0.07^{\mathrm{B}}$ & $0.14 \pm 0.12^{\mathrm{C}}$ \\
\hline & 12.5 & $1.19 \pm 0.28^{\mathrm{B}}$ & $1.17 \pm 0.37^{\mathrm{B}}$ \\
\hline \multirow[t]{4}{*}{ Lipid } & 2.0 & $5.30 \pm 0.04^{\mathrm{A}}$ & $5.28 \pm 0.62^{\mathrm{A}}$ \\
\hline & 3.0 & $1.64 \pm 0.25^{\mathrm{C}}$ & $1.97 \pm 0.10^{\mathrm{B}, \mathrm{C}}$ \\
\hline & 11.5 & $0.98 \pm 0.25^{\mathrm{C}}$ & $0.85 \pm 0.31^{\mathrm{C}}$ \\
\hline & 12.5 & $2.69 \pm 0.49^{\mathrm{B}}$ & $2.72 \pm 0.59^{\mathrm{B}}$ \\
\hline \multirow[t]{4}{*}{ Protein } & 2.0 & $3.70 \pm 0.14^{\mathrm{A}}$ & $3.81 \pm 0.10^{\mathrm{A}}$ \\
\hline & 3.0 & $1.12 \pm 0.35^{\mathrm{C}}$ & $1.10 \pm 0.34^{\mathrm{B}}$ \\
\hline & 11.5 & $1.08 \pm 0.12^{\mathrm{C}}$ & $0.97 \pm 0.10^{\mathrm{B}}$ \\
\hline & 12.5 & $2.01 \pm 0.50^{\mathrm{B}}$ & $1.89 \pm 0.61^{\mathrm{B}}$ \\
\hline \multirow[t]{4}{*}{ Water } & 2.0 & $6.60 \pm 0.22^{\mathrm{A}}$ & $6.77 \pm 0.54^{\mathrm{A}}$ \\
\hline & 3.0 & $3.54 \pm 0.42^{\mathrm{C}}$ & $3.65 \pm 0.38^{\mathrm{C}}$ \\
\hline & 11.5 & $4.19 \pm 0.20^{\mathrm{C}}$ & $4.14 \pm 0.26^{\mathrm{B}, \mathrm{C}}$ \\
\hline & 12.5 & $4.92 \pm 0.15^{\mathrm{B}}$ & $4.78 \pm 0.04^{\mathrm{B}}$ \\
\hline \multirow[t]{4}{*}{ Total } & 2.0 & $3.05 \pm 0.46^{\mathrm{A}}$ & $3.09 \pm 0.36^{\mathrm{A}}$ \\
\hline & 3.0 & $0.66 \pm 0.31^{\mathrm{B}, \mathrm{C}}$ & $0.73 \pm 0.26^{\mathrm{B}, \mathrm{C}}$ \\
\hline & 11.5 & $0.16 \pm 0.06^{\mathrm{C}}$ & $0.04 \pm 0.05^{\mathrm{C}}$ \\
\hline & 12.5 & $1.11 \pm 0.31^{\mathrm{B}}$ & $1.07 \pm 0.41^{\mathrm{B}}$ \\
\hline
\end{tabular}

A,B,C Values designated with the same letter within a column are not significantly different $(P<0.05)$. 
Figure 1. A flowchart for the isoelectric solubilization/precipitation protein recovery process for whole gutted rainbow trout and subsequent analyses of the recovered fractions.

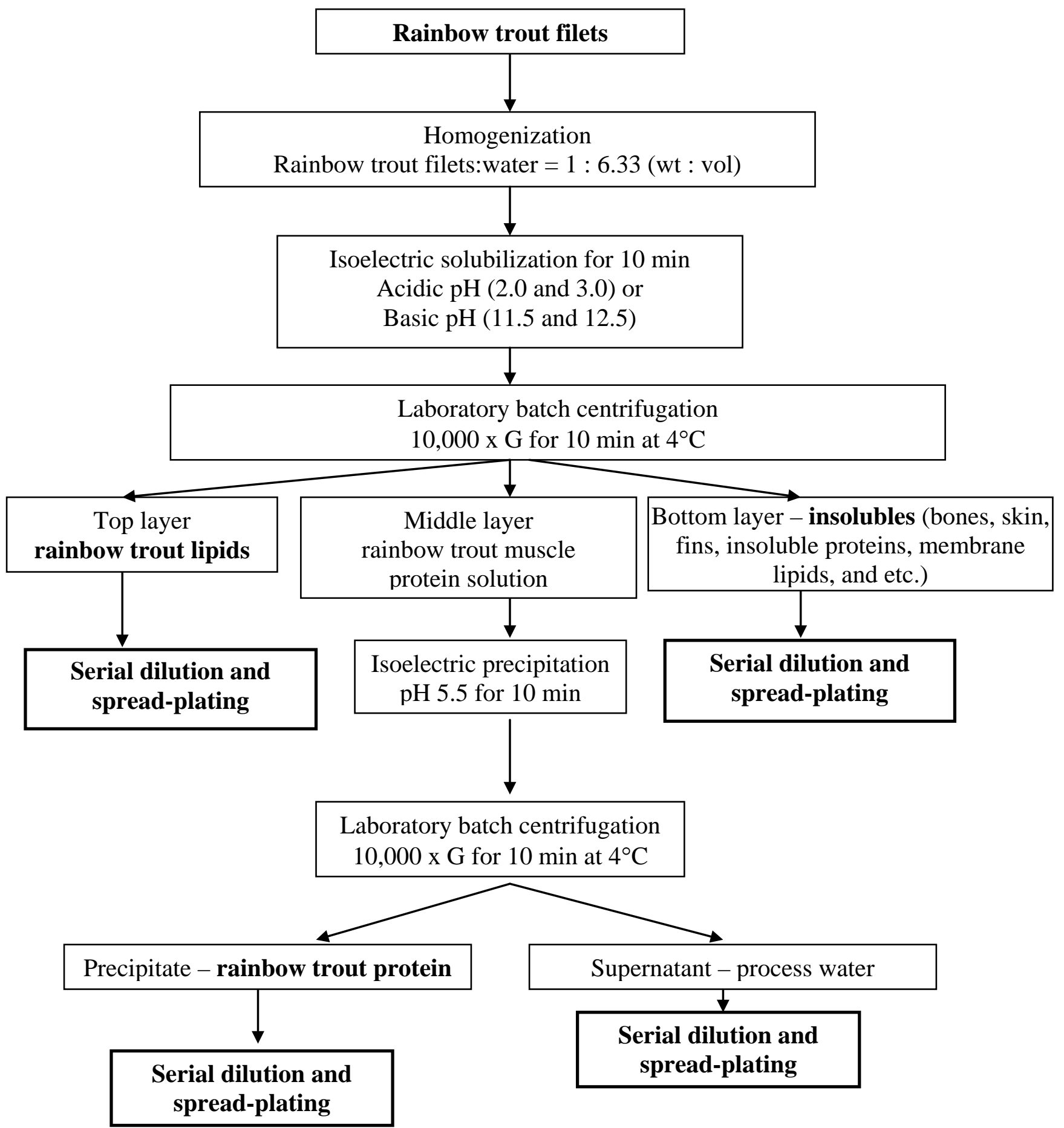


Figure 2. Recovered L. innocua after acidic $p H$ shift. Pie chart on left represents recovered cells from the initial inoculum; whereas the pie chart on the right represents the amount of cells recovered from each fraction.

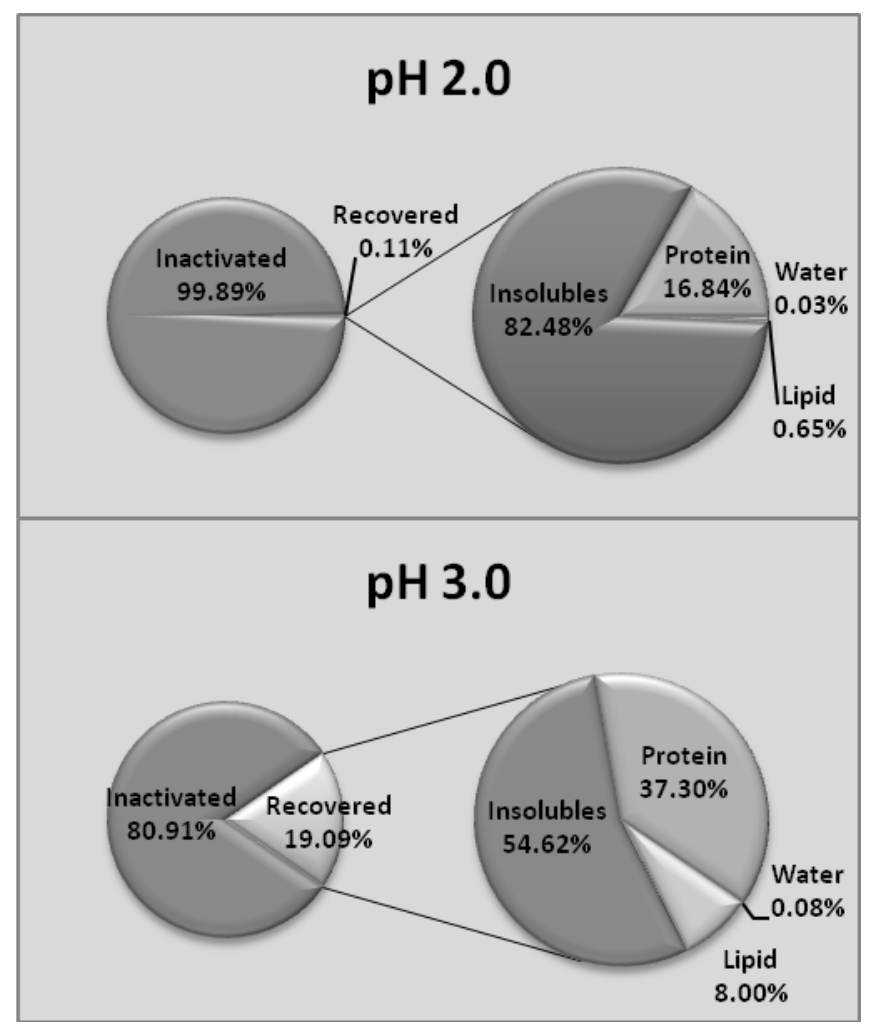


Figure 3. Recovered L. innocua after basic $\mathrm{pH}$ shift. Pie chart on left represents recovered cells from the initial inoculum; whereas the pie chart on the right represents the amount of cells recovered from each fraction.

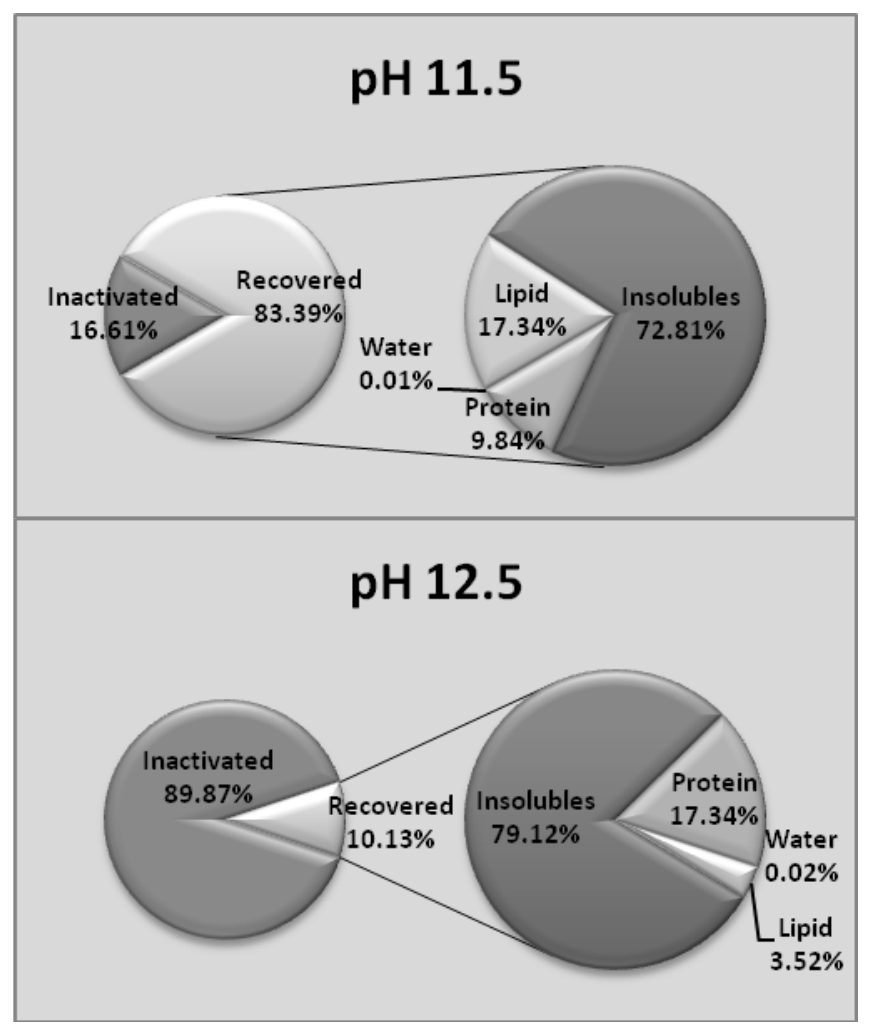

